\title{
Interfaces
}

\section{Signals Crossing Borders: Cybernetic Words and Images and 1960s Avant-Garde Art}

John A. Tyson

\section{(2) OpenEdition}

1 Journals

\section{Electronic version}

URL: http://journals.openedition.org/interfaces/312

DOI: $10.4000 /$ interfaces.312

ISSN: 2647-6754

\section{Publisher:}

Université de Bourgogne, Université de Paris, College of the Holy Cross

\section{Printed version}

Date of publication: 1 January 2017

Number of pages: 65-103

ISSN: 1164-6225

\section{Electronic reference}

John A. Tyson, « Signals Crossing Borders: Cybernetic Words and Images and 1960s Avant-Garde Art », Interfaces [Online], 38 | 2017, Online since 13 June 2018, connection on 04 January 2021. URL: http://journals.openedition.org/interfaces/312 ; DOI : https://doi.org/10.4000/interfaces.312

Les contenus de la revue Interfaces sont mis à disposition selon les termes de la Licence Creative Commons Attribution 4.0 International. 


\title{
SIGNALS CROSSING BORDERS: CYBERNETIC WORDS AND IMAGES AND 1960S AVANT-GARDE ART
}

\author{
John A. Tyson
}

\begin{abstract}
We hope to provide a forum for all those who believe passionately in the correlation of the arts and Art's Imaginative integration with technology, science, architecture and our entire environment. We believe that such an integration can only be accomplished by most rigorous means: by the exercise of the highest academic standards, and when society gives to the artist its available materials, its support, and complete freedom in the pursuit of his (the artist's) art.
\end{abstract}

\section{—David Medalla and Paul Keeler}

This frank, hopeful introduction appears on the front page of the first issue of the avant-garde publication Signalz: Newsbulletin of the Centre for Advanced Creative Study (the sole one that employs a deviant " $z$ " spelling) (Fig. 1). Eleven numbers of Signals appeared between August of 1964 and March of 1966. The periodical was a textual supplement to the programming of a doubled enterprise: the Signals Gallery, which was coextensive-initially selfsame-with the Center for Advanced Creative Study mentioned in the full title. A pair of young impresarios directed Signals, the Philippine poet and artist David Medalla (b. 1942), the bulletin's primary editor, and British curator and critic Paul Keeler (b. 1942) who oversaw gallery programming. Additionally, musician Christopher Walker, the artists Gustav Metzger and Marcelo Salvadori, and the curator and critic Guy Brett were co-founders of the Centre for Advanced Creative Study and regular collaborators (Brett, Exploding Galaxies, 46-47). The less technocratic name, Signals Gallery, was adopted when they shifted operations from an apartment at 92 Cornwall Gardens to a four-story building at the corner of Wigmore and Welbeck streets in Central London, a move which coincided with the Newsbulletin's second issue (the name dropped from the masthead by the third issue).

By their names, there is a suggestion that both Signals undertakings (Gallery and Newsbulletin) were technologies for broadcasting information. The broadsheet was, moreover, the textual manifestation of a London-based multiplatform social network, consisting of an informal band of European and Latin American artists and critics, the Signals Group. Possibly to an even greater extent than the gallery, the 

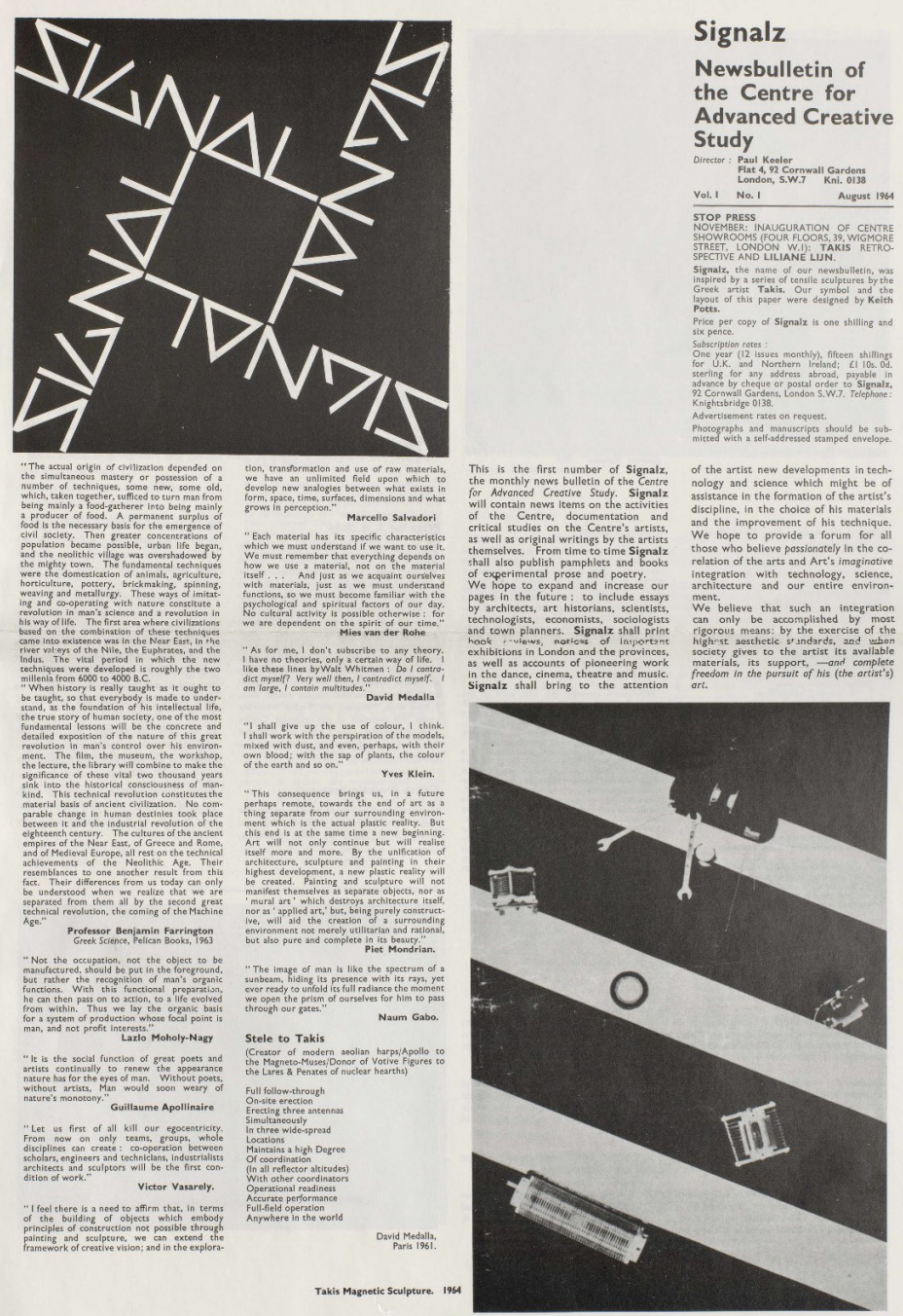

Fig. 1. Front page of Signalz: Newsbulletin of the Centre for the Advanced Creative Study 1.1 (August 1964). (C) David Medalla and Paul Keeler. 
publication amplified group members' artworks and ideas, which circulated internationally via the pages Signals. The journal's distribution of words and images served a deterritorializing function: the editors aimed to engender the kind of utopian, transnational "global village" that cybernetician and media theorist Marshall McLuhan imagined the modern media could yield (Understanding Media 46). Further licensing Keeler and Medalla's endeavor, McLuhan also believed that it was artists who were best suited to grasp the implications of new technologies: "The serious artist is the only person able to encounter technology with impunity, because he is an expert aware of the changes in sense perception" (The Medium is the Massage 7).

A dialectic between center and margin played out with Signals globalized operations: the gallery was a technology that brought art from Latin America to a hip European metropolis; conversely, the Newsbulletin liberated art and ideas from geographical centers and their conventions of presentation. Albeit to a lesser (but not insignificant) extent, Signals worked to bring East and West together too. The periodical resisted the Cold-War era's binary world order by reporting on developments from both sides of the iron curtain. In number 3/4 (October-November, 1964), a photo of cosmonaut Yuri Gagarin appears alongside kinetic sculpture. In the next issue, they ran John Newell's discussion of U.S. and Russian achievements in "The New Space Race" (December-January, 1964/65). Moreover, the Russian Avant-Garde's relevance for the present moment is alluded to in nearly every issue. This Soviet body of work was still extremely fresh in the 60s, as little had been seen in the West until the British art historian Camilla Gray's The Great Experiment: Russian Art, 1863-1922 (1962). This tome introduced Suprematism and Contructivism to a new generation searching for forms that connoted rebellion, if not revolution. Indeed, Medalla and Keeler's publication and gallery struck a specific political stance. Their focus on Latin American art and artists implied a refusal to view New York and the United States as the center. Rather, they militated to produce alternative artistic constellations.

As this essay's epigraph implies, in addition to crossing geographic borders and considering art as part of its system, Signals: Newsbulletin transcended disciplinary bounds. Its creators imagined a resolution of forms of creativity, blurring C.P. Snow's "two cultures" in order to poetically "misuse" science and technology for art. ${ }^{1}$ In order to achieve this primary directive, the magazine was highly citational, bringing together words and images that would not typically be imprinted on the same folio. This logic began with the journal's name. Keeler and Medalla borrowed the title from a series of tensile sculptures made by the Greek kinetic artist Panagiotis Vassilakis (known as Takis). Combinations of

British chemist Charles P. Snow's influential discussion of the arts/sciences divide in The Two Cultures was widely discussed within advanced art circles during the 1960 s. 
text and images were tightly "curated," juxtaposed for rhetorical and aesthetic ends. The Newsbulletin reprinted numerous quotes, articles, scientific reports, diagrams, and poems - deftly weaving them together with new content.

Drawing on the insights of art historian Gwen Allen in relation to U.S. magazines, I propose that Signals: Newsbulletin was "an alternative space for art" (Fig.1). The broadsheet went beyond mere art documentation or publicity (though it did fulfil both of these functions). The printed page is a platform for display, a place of virtual exhibition. It was arguably equally important, if not more so, than the Signals Gallery for the spread of vanguard art information. The move to the print was not just a translation, but also process of mutation: texts and images (both signals imprinted on the page) inflect and even infect one another; layout and graphic design decisions enabled new meanings and intersubjective author positions to emerge. Through whimsical combinations of content, readerviewers ideally saw an expansion of their imaginations. Indeed, an advertisement in issue 3/4 impels readers to "join us in our quest for an imaginative life" by paying a modest 30 shillings (about 302016 dollars) to subscribe. Blazing new paths for art with techno-poetics, Signals: Newsbulletin significantly anticipates developments in art and art publishing that would emerge only a few years later in North America and Europe.

David Medalla led an itinerant existence. Born into a well-off family in Manila, he was a child prodigy. As an adolescent Medalla published poems, translated William Shakespeare's Hamlet into Tagalog, and undertook anthropological fieldwork with the Igorot and Ifugao peoples in the Philippines. His continued interest in first-nations peoples is manifest in photos and texts that appear in many editions of Signals. He enrolled at Columbia University as a special student at age 12 (Mitichison). After his time in New York, he moved to Paris, where he became a student of philosopher of science Gaston Bachelard and immersed himself in Surrealism. His artistic breakthrough came with pioneering foaming kinetic sculptures entitled Cloud Canyon (1963-68). The British half of the partnership was the son of a wealthy optical instruments manufacturer. Keeler initially tried his hand at acting before shifting toward art; in the early 1960s, he started a small business as a canvas primer. Later, he would become an authority on Islamic art and develop a scholarly network for addressing art of the ancient world.

Medalla and Keeler's relationship predated Signals. The men had been flat-mates in Little Venice, Paddington since 1962. In 1963, Keeler organized the first U.K. exhibition of Medalla's paintings and drawings. Their curatorial collaboration began to take further shape following a 
transformative trip Medalla took to Paris. In the French capital he encountered the kinetic works of Takis, the Belgian Pol Bury, and the Venezuelan Jesus Rafael Soto at Galerie Diderot; immediately struck by these artworks, he returned to the U.K. profoundly affected. By 1964, he had turned Keeler on to kineticism: Keeler organized two pioneering exhibitions of kinetic art-Structures Vivantes: Mobiles/Images at the Redferm Gallery and Soundings at Oxford's Ashmoleum Museum. A sequel or encore show, Soundings Two, was held at Signals from July-September, 1965.

\section{A Trasnational Mosaic}

The first edition of the Newsbulletin commences with lines from a range of sources, bringing them together in order to produce a modern textual mosaic. This multi-faceteted figure was the structure that McLuhan used as a metaphor for the diverse, ever-shifting modern media. Following the Canadian cybernetician, this tiled structure made of "numerous data and quotations in evidence offers the only practical means of revealing causal operations in history" (Gutenberg Galaxy, 1xii). In Signalz, the words of the classicist and historian of science Benjamin Farrington, the poet Guillaume Apollinaire, Bauhaus masters Mies van der Rohe and Lazlo Moholy-Nagy, the de Stijl group's Piet Mondrian, and constructivist Naum Gabo are mixed alongside contemporary voices: those of the recently deceased Yves Klein, op artist Victor Varasely, and, rather conspicuously, the journal's principal editor too. Medalla's quote reflects his interests in citation, his love of poetry, and his publishing approach to open up authorship: "I don't subscribe to any theory. I have no theories, only a certain way of life. I like these lines by Walt Whitman: Do I contradict myself? Very well then, I contradict myself. I am large, I contain multitudes" ("Signalz," 1).

Looking back on his career, Medalla described his activities as "a spiritual adventure in understanding contemporary culture in the fields where art and science converged in harmony and energized each other" (qtd. in Nankervis, "A Stitch"). He used nearly the same language for Signals. The slogan that ran in a number of the earlier issues (numbers 2, 3/4, and 5) affirms it was "dedicated to the adventures of the modern spirit." Despite bearing witness to the more dismal side of science with the creation of the atom bomb, there continued to be a great deal of faith placed in new scientific and technological developments in the 60s. According to art critic and Signals regular Guy Brett, an important voice on kinetic art, a kind of scientific utopianism unimaginable today characterized the era. For example, Medalla was very influenced by Werner Heisenberg, to whom he wrote a "fan" letter to and viewed as a "pure" scientist—despite Heisenberg's work with the Nazis (Lee 127). Medalla 
republished the physicist's discussion of science and philosophy, "The Role of Modern Physics in the Present Development of Human Thinking” in Signals 9 (August-September-October, 1965).

Medalla was not shy about promotion. In the introductory remarks of Signals 2, he writes there has been "a big jump for a second number and one that surely heralds bright exciting things to come" ("Signals 2" 2). Data about the reach of the journal appears in a column on the second page of the second issue, which also transmits messages about the pool of collaborators. The magazine had quickly augmented in scale, equally in terms of contents and readership. For Signals 2 the editors expanded the number of pages to sixteen. The circulation expanded also, more than tripling to 10,000. In addition, the graphic design grew richer over the course of the publication's two-year run: colored and metallic inks - usually of a distinct variety of hues for each issue - appeared in later issues, further enlivening the pages.

The second iteration was "prepared with the cooperation and assistance of the Embassies of Brazil, Mexico, Uruguay, Venezuela and other Latin American countries" (Medalla, "Signals 2" 2). As issue two's introduction highlights, Signals had a global reach. It spanned aesthetics and international politics. Coopting the resources of the British Council as well as "many embassies and consulates in London," the periodical apparently traveled to "outposts in all the corners of the word" via diplomatic cultural networks (Medalla, "Signals 2" 2). While it is difficult to determine whether these claims were not a little overblown, Signals is today found in libraries in South Africa, New Zealand, Australia, as well as across Europe and North America.

In addition, Signals circulated via airmail systems and partook in an epistolary culture. Rather charming photos of the gallery's associates seated on the carpet, working collectively to attach mailing labels provides concrete evidence of this operation. The Newsbulletin reached publics in both hemispheres and on both sides of the Atlantic. Various figures in the orbit of the Northeastern United States, as tech-art gurus Jack Burnham and György Kepes, the American critic Dore Ashton (best known for her writings on abstract expressionists at this time, but who later weighed in on tech art), or the German-American artist Hans Haacke received the transmissions. These readers subsequently were activated as collaborators: altering positions, the one-time readers at various times composed letters that Signals published (Haacke also contributed photos of Takis's projects).

Signals provoked a shift in the art world, in the words of The Observer's James Fox (reprinted in Signals 1.9), "From North to South." Signals introduced many South American artists to the AngloAmerican art world. For instance, the first U.K. exhibition of Brazilian artist Lygia Clark was held at 
the gallery in 1965. The journal ran extensive features on, Jesus Soto, Carlos Cruz-Diez, Alejandro Otero, and Sergio de Camargo, artists not well known in the UK at the time. Keeler and Medalla met Camargo in Paris, and through his contacts, familiarized themselves with "the whole Latin American, but especially Brazilian art scene" (Brett qtd. in Lee 131). The Newsbulletin was a valuable source of texts by the artists themselves as well as critics of their works. Thus, Signals was very important for contextualizing their work for British audiences. But it did not solely provide the interpretations by critics or curators, the artists are given the opportunity to help determine the meaning of their works. On one hand this move seems to extend a kind of cult of the artist (which was partially undermined by the other voices and Medalla's designs); on the other, it tacitly questioned the norms of authority that govern art and art discourse.

Furthermore, the journal anticipates ideas about alternative transnational constellations that developed in the later 1980s. Gerardo Mosquera, curator of the Second Havana Biennial (1986), famously advocated for a reimagining of contemporary art that would promote "south-south-south" connections and contest the English-language hegemony of art. Mosquera decried the way that Manhattan-based institutions had a monopoly on the conferral of "advanced art" status. The Signals Gallery and Newsbulletin provided a space to imagine and inscribe this set of relations and transcendence of Anglophone views on art. By showcasing works from artists hailing from the Southern hemisphere and reproducing texts in a range of languages, Signals anticipated and even helped commence the global turn in art.

\section{A Little Historiography of Signals}

Suggesting the magazine continued to be of great relevance for transnational art, The Institute of International Visual Arts (commonly known as InIVA) released an exacting boxed facsimile edition of the entire run, complete with a new index, in 1995. ${ }^{2}$ Nevertheless, Signals Newsbulletin has not previously received holistic art-historical assessment. In contrast, the later vanguard French publication Robho (edited by Jean Clay) was profiled in the journal Third Text by Isabel Plante and addressed by Allen in Artists' Magazines. Given the common pool of contributors and artists — as well as the fact that

2 Based on a comparison with the original issues of Signals held in the library of the Museo Nacional Centro de Arte Reina Sofia, the two editions are nearly identical. Apparently, 1000 copies of the InIVA edition were printed. 
Signals artist Carlos Cruz-Diez designed the layout—Signals must be seen as foundational. Robho was certainly inspired by the earlier magazine and in some sense, assumed the mantle of promoting Latin American art in Europe (Cruz-Diez and Jiménez 72).

Guy Brett, a pioneering curator and critic of kinetic art, who wrote for both magazines, discusses Signals in Exploding Galaxies, his monographic study of the oeuvre of his friend David Medalla. Brett views Keeler and Medalla's publication and gallery as epitomizing the experimental spirit of their time. Brett suggests that their embrace of material from assorted disciplines and tendencies may have contributed to art historians' unease or inability to deal properly with Keeler and Medalla's project: " Orders' of art history tend to be linear and chronological. But movements can also be understood in the way they spread out sideways or in all directions" (40). He also emphasizes the parity between poems and criticism in Signals. Brett argues that Medalla had an amazing capacity to blend the playful and fantastic with pragmatic organizational skills, which carried over to the "lavish" Newsbulletin (49). He specifically points to the "MMMMMMM . . . Manifesto" that Medalla published in Signals 1.8 - which oneirically outlines alternate functions for new technology - as an instance of the artist "weav[ing] together the roles of pragmatic 'maker' and unrestrained 'dreamer"' (63).

Pamela Lee discusses the Signals Gallery and Newsbulletin in tandem in Chronophobia, an important treatment of shifting relations to a time in 1960s art. Lee identifies their lack of interest in North American art and hones in on what she calls Signals Gallery's "imaginative' character" (127). She insightfully suggests that "its interests were in articulating new perceptual modes for the spectator, anticipating the effects introduced by modern science through seeing works of art as vehicles of energy" (127). Perceptively, Lee argues that a parallel drive for expansion might conceptually link Medalla's expanding "living" foam sculptures to the group $(128 ; 130)$. Though she does not state it explicitly, Lee's arguments about art as a "vehicle of energy" capable of "retraining" the imagination should be extended to the gallery's publication as well (127).

\section{The Backdrop of "Swinging London"}

In 1966, Paul Hogarth and Malcolm Muggeridge created an insider's view of London in word and image with caricatured line drawings, updating William Hogarth's satirical and moralizing views of British life in ironical tone proper to the later twentieth century. They are frank in their view of the metropolis as the epitome of modern, urban life: 
Our hopes and dreams are written up in coloured lights, presented on screens in movement and colour; enlarged in a close-up of a body, a face, a magnified morsel of delectable flesh [...]. Our heaven is earth, and London is its capital. London growing ever larger, sprawling ever further $[\ldots]$ going ever faster. London! $(104 ; 108)$

It was in this environment of kaleidoscopic sensory overload that Signals emerged. Located at the 39 Wigmore Street, in London's fashionable West End, a mere two blocks north of the major commercial artery of Oxford Street, the gallery introduced many new artistic forms to the U.K. scene. By its cutting edge contents, the art space and its associated Newsbulletin progressed very much in lockstep with the hip, bubbling metropolis. While transnational, Signals surely capitalized on the cool reputation of its location, much like more traditional commercial ventures. For example, advertisements for a boutique in walking distance, I was Lord Kirchner's Valet, similarly tout their situation in London.

International audiences increasingly viewed the British capital as a happening global city. Just a month after the final issue of Signals, a TIME cover story profiled the city's changing climate. After describing the "great" metropolises of other decades of the twentieth century, the periodical affirms: "Today, it is London, a city steeped in tradition, seized by change, liberated by affluence [...]. In a decade dominated by youth, London has burst into bloom. It swings; it is the scene./ This spring, as never before in modern times, London is switched on" (38). The TIME article in many ways echoes Hogarth and Muggeridge's assessment. The "Swinging London" report is structured like a movie script, suggesting that the images reported perhaps also conform to Hollywood notions of 60s England. ${ }^{3}$ Despite the fact TIME presents some of the stereotypes the magazine's primarily North American readership expected, the profile captures the city's youthful energy and cultural trends: London was a "groovy" place where rock and rollers were the new royalty, disco, sexiness, verve, and vulgarity were in, sartorial sharpness and shaggy haircuts prevailed, and a vibrant art scene incubated op and pop - tendencies which extended beyond the galleries to color everyday design and fashion. The revolutionary spirit that characterized the 1960s certainly extended to the world of art: Kinetic art was often quite literally "switched on" (TIME 38.).

\section{The Political Stakes of the "Kinetic Kraze"}

Much as in broader Western society, the new generation positioned itself against the old status quo. Within art, the critical paradigm of "arch-modernist" Clement Greenberg and the associated

3 The writer mentions Michelangelo Antonioni’s classic depiction of the London scene, Blow-Up [1966], which was being shot on location at the time. 
styles of Abstract Expressionism (termed "American-type painting" by Greenberg) and Post-painterly Abstraction became anathema to younger advanced artists. Artists rejected traditional competence, ideas of working in a single, traditional medium, such as painting or sculpture, and the autonomy of art (the idea that works should not react to the presence of viewers).

Modes of artmaking that today are often separated into distinct taxonomies in museums or undergraduate survey courses were all part of one unruly field of contemporary culture. Signals brought together neo-concrete art, kinetic art, tech art, and minimal art—works which at the time were all understood under the rubric of "constructivism." Kinetic artist George Rickey's Constructivism: Origins and Evolution (1967) as well as various exhibitions (perhaps most notably Plus by Minus, Today's Half Century [1968], and The Machine at the end of the Mechanical Age [1968]) helped to concretize this field of production. The use of the term constructivism, which was also employed to describe earlier projects by Gabo, Mondrian, or Lissitsky, linked new art of the 1960s with works hailing from the first decades of the twentieth century. Rickey locates many Signals artists, including Cruz-Diez, Clark, Soto, Takis, Medalla, Le Parc, and Haacke within this category.

One of the clearest commonalities found in the new varieties of art that emerged in the 1960s was a concern for time and temporality. Critic Michael Fried celebrated "presentness" and took to task the "theatrical" aspects of minimalism in his famous censure "Art and Objecthood." Comparatively, the projects of the American minimal artists whom Fried took objection with seem downright inert beside the kinetic works shown at Signals Gallery. Medalla strived for all of his projects to approach the condition of dynamic life. By existing coextensively in time with spectators and often reacting directly to them, the new art seemed capable of resisting the notion of art as precious and timeless: it was real.

The Frankfurt school theorist Herbert Marcuse, a major figure in the 1960s, supported this notion. Marcuse affirms: "And history perhaps now is catching up with art, or art is catching up with history. The historical locus and function of art are now changing. The real, reality, is becoming technique in a literal, 'practical' sense; making and remaking things rather than painting pictures [...]" (121). As his words indicate - in what now may seem like a slightly naïve rhetorical sleight of handnew art forms were understood to possess an automatic political charge. Undergirding this belief about art's transformative powers was the reasonable assumption that art reflects the society that it was produced in. Artists aimed to reverse engineer this process: they held that radical types of art contained the promise of societal change. 
Greenberg's term, "American-type painting," contributed to a further sense that abstract expressionism constituted a national school approved by the U.S. Government that tacitly forwarded its agenda. ${ }^{4}$ Another 1966 TIME magazine article describing the tendency to make artworks that actually travelled through time and space dubbed kineticism "the movement movement"-implicating the tendency in a field of other counter-cultural — and not just artistic - movements. Further suggesting that resisting the status quo in art was tantamount to resistance of the hegemonic order of things in the socio-political realm, only a few years after Signals was published, MoMA curator Kynaston McShine affirmed that given the political climate: "If you are living in the United States, you may fear that you will be shot at, either in the universities, in your bed or more formally in Indochina. It may seem too inappropriate, if not absurd to get up [...] and apply dabs of paint from a little tube to a square of canvas" (unpaginated). ${ }^{5}$

\section{A Newspaper Aesthetic ...}

Signals Newsbulletin was in many ways different from contemporary art journalism. It diverged from most "little magazine" artists" publications as well as the larger, codex format that continues to characterize trade journals like Artforum. Medalla and Keeler's broadsheet adopted a periodical aesthetic. The bi- or tri-monthly journal took on the form of newspapers, though not their cheaper pulp paper. Its use of bold color, graphic design, varied typeface, and touch of red in issue one, all make the glossy broadsheet resemble tabloids of the day. Signals included sections with the heading "Stop Press," a phrase commonly printed in British papers to indicate that even more upto-date news had been added. As well as mimic the techniques of the media by vocabulary, Signals's use of "stop press" sections - in courier type and sometimes with more than one per issue-suggested that the authors were packing in as much data as possible, continuously out on the beat for information or receiving wires - like the writers of standard dailies. Though it may have been as well the result of a lack of organization, the inclusion of "stop press" served to add a clear sense of temporality and contemporariness into the publication.

4 These concerns were not unfounded. As Eva Cockcroft and Max Kozloff have proven, the Rockefeller Brothers in tandem with the CIA instrumentalized Abstract Expressionism, turning it into a Cold War weapon.

5 A number of the artists whose work was featured in Signals were included in McShine's important Information (1970) at MoMA, for which he composed the quote. 
Indeed, Signals emphasizes contingency and the possibility of re-use, over absolute timelessness for the art and texts it contains. Because the publication was folded rather than bound, the possibilities of pulling, spreading it apart over space or reconfiguring the text do certainly exist. Moreover, by paralleling the "low," even throwaway form of the paper, it confounds hierarchical divisions of "high_-" and "low_-" brows of culture.

Newspapers are an ephemeral, mass medium that in the sixties - like today - typically transmitted factual information in a single language. With a geo-politically bounded readership, newspapers traditionally build perceived connections between citizens of one nation-state. ${ }^{6} \mathrm{~A}$ sense of belonging to a common polity can be born out of simultaneous reception of common content. Transcending monolingualism (and thus, nationalism), Signals variously contains texts in English, French, Spanish, Portuguese, and Greek, as well as many translations. The Newsbulletin brought together many kinds voices, yielding a decidedly polyphonic and cosmopolitan montage of content that aligned with their globalized vision of the art world. Signals served to foment an imagined transatlantic community of artists and thinkers.

In the July-August 1965 issue Medalla published an excerpt of a 1964 letter sent from Germany by Hans Haacke alongside a French language telegram he wrote in reply to the GermanAmerican artist: given the layout and deployment of typographic elements - a vector of full stops and larger black dots that mark section breaks - there is an implication that Signals is the high-velocity delivery device for the electronic message. The journal's temporality of exchange was of course not that of the rapid telegraph. Nevertheless, Keeler and Medalla were not the first to evoke modern communication technology as part of an endeavor in newspaper publishing: the Daily Mail and Daily Telegraph, established respectively in 1896 and 1855, also make a similar link between papers and other modes of communication. ${ }^{?}$

$6 \quad$ For more on newspapers and national identity see Benedict Anderson, Imagined Communities: Reflections on the Origin and Spread of Nationalism, revised edition (London: Verso, 2006).

7 The Spanish translations of these terms, el telegrama and el correo are also periodical names in Spain and Latin America. 


\section{Works on Paper}

In some issues of Signals, depictions of works appear with limited text on a spare white ground, recalling the display of objects within the white cube gallery. For instance, works by Alejandro Otero occupy almost the entity of the space and are accompanied by limited captioning, characteristics that prompt them to read as presentation rather than representation. Flows of depictions of works by Carlos Cruz-Diez, selected and captioned by the artist, snake through Signals 1.9-emphasizing the spatial aspects of the paper (Fig. 2). The reader-viewer must "make an effort to discover" the images, navigating through the pages to view the entire photo-strip (Cruz-Diez 5).

Signals was at the crux and vanguard of a variety of period artistic tendencies: the print renaissance saw the creation of an increasing number of printed portfolios that collect the work of various artists. While in 2016 kinetic art might seem a world away from printmaking, they were both understood as instances of a mastery of technics and requiring skillful manipulation of complex tools. ${ }^{8}$ Signals can also be set into a voguish genealogy of co-productions, collections of multiples that include poet Walasse Ting's 1-Cent Life (1963); the Wadsworth Athenaeum's X+X (TEN WORKS BY TEN PAINTERS) (1964) (which was curated by Samuel Wagstaff Jr.); Jack Sonenberg's Artists and Writers Protest Against the War in Viet Nam (1967); and gallerist Leo Castelli's Ten from Leo Castelli (1968).

In Europe, artists like Victor Vasarely advocated for the creation of reproducible abstract "prototypes." Vasarely helped found the Parisian Galerie Denise René, which produced prints and multiples by kinetic and op artists. Cologne's Galerie Der Spiegel operated similarly in Germany. Again revealing that Signals was ahead of the curve: a broader renewal of interest in Bauhaus notions (which had always percolated in the U.S. thanks to Moholy-Nagy, Josef Albers, and Gyorgy Kepes) of

8 This idea about printing relating to tech art is clearly expressed in the essay for the Museum of Modern Art's exhibition surveying the output of the pioneering Los Angeles print studio, Gemini G.E.L. See Riva Castleman, Technics and Creativity: Selections from Gemini G.E.L. exh. cat. (New York: Museum of Modern Art, May 5July 6, 1971), 7-31. Castelman touches upon constructivism and the Bauhaus in the process of tracing art history in relation to printmaking. The fact that Gemini was willing to undertake projects in all manner of media, including a kinetic ice bag sculpture, Ice Bag-Scale C, with Claes Oldenburg surely aided in making the association. The press release for the exhibition further highlights the hydraulic press and rag paper Gemini developed to the meet artist's needs. 


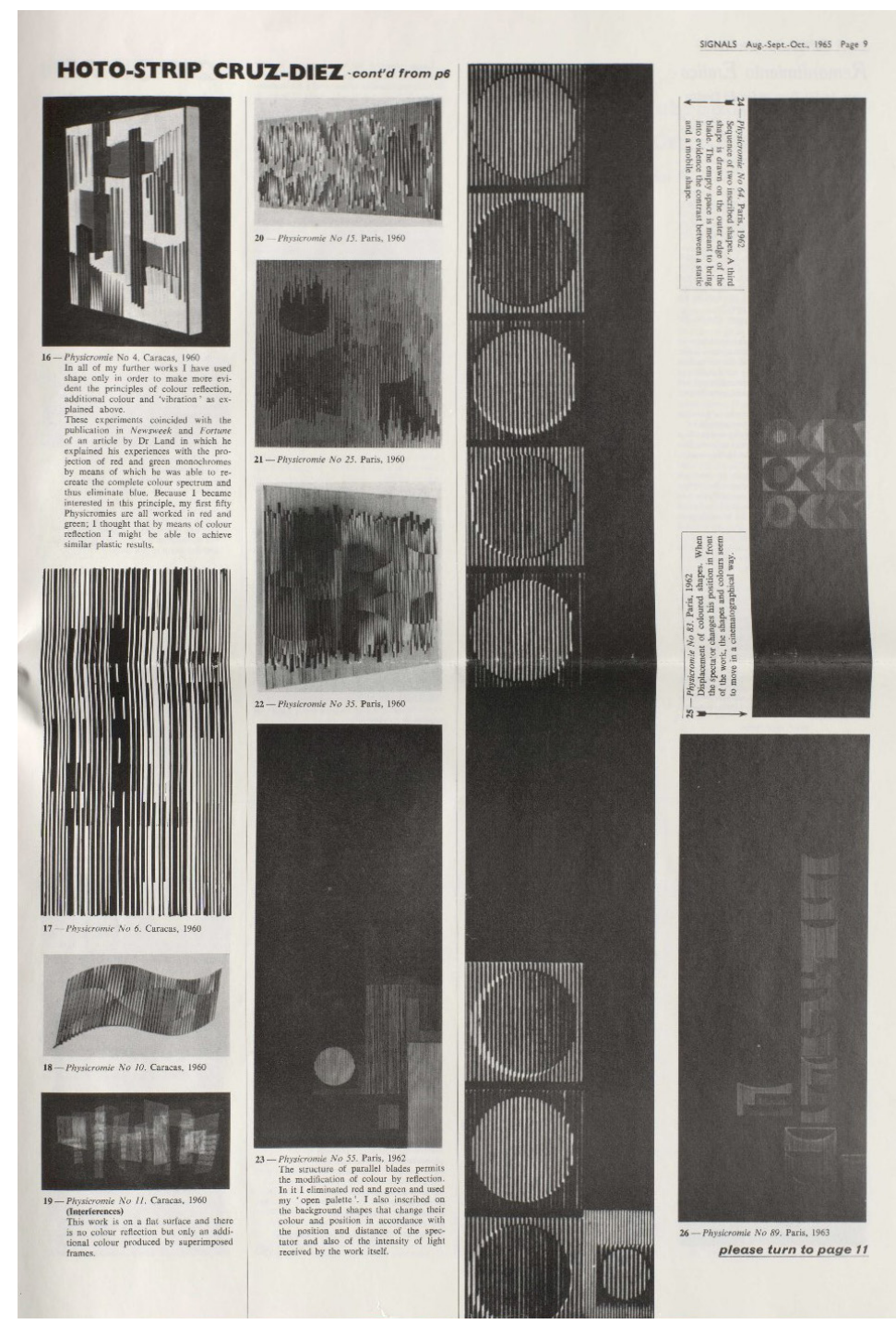

Fig. 2. Carlos Cruz-Diez, "Photo-Strip Cruz-Diez," Signals 1.9 (August-September-October, 1965), 9 . 
collective artistic labor and the ideal of a mechanically made mass-produced art can in part account for the "multiplicity" trend. ${ }^{9}$

Additionally, by modeling vanguard strategies of reading and writing, Signals anticipates primarily American magazines being used as alternative exhibition spaces. Moreover, in the years following its production magazines like Artforum or Arts, Signals would host for printed artworks. Unlike these magazines, in which the art was disguised as articles or advertisements in an otherwise straight publication, Signals functioned as a total art network. It was a technology that blurred the bounds between art and science, article and work; as new content appears simultaneous to reproduction, typical designations between presentation in the gallery and representation in the publication break down and merge. Like the "wordworks" found in many other publications of the period, Signals disregarded traditional notions of aesthetics and veered toward an art that was liberated from gallery presentation and conventions of artistic media. Thus, the publication spanned what the critic of Lucy Lippard called "dematerialization" and a concern for materiality.

The 1960s did not just see a return of the Bauhaus. Marcel Duchamp's influence was increasingly felt. For all the cases named above, Duchamp's famous Boitte-en-valise must be viewed as an important precedent. The Boite is a multiple issued various times between 1940 and 1973 (and again in 2015). The artwork consists of deluxe, hand-colored miniaturizations of the French Dadaist's oeuvre. It is almost certain that Signal's director and editor would have been familiar with the Boite. Duchamp's writings appeared in the broadsheet and Keeler exhibited his work in the gallery. In fact, the flow of influence between Duchamp and Medalla was multi-directional. Duchamp was an important precedent for the Cloud Canyons, as he was (likely) the first artist to use foam; he playfully converted himself into a demon or fawn for the self-portrait on Monte Carlo Bond (1924). According to Medalla's collaborator Adam Nankervis, the Philippine kineticist showed his first bubble-machine sculpture to Duchamp's friend Man Ray in Paris; apparently, Keeler also shared images of Medalla's works with Duchamp, who was inspired to produce a multiple, Medallic Sculpture (1964/68) ("David Medalla"). This multiple is a multivalent pun on the younger artist's name and the round form (medal) and material (metal) employed, which paid "tribute to David Medalla and his bubble-machines" (Nankervis, "A Stitch").

9 Susan Tallman argues that for Albers it was important for him that Ken Tyler, the master printer at Gemini, apply the ink to the stone for his lithographs in 1966 and 1967. Interestingly, the Bauhaus artist also employed post systems for the works done with Gemini: he developed his nested squares compositions on a piece of cardboard and mailed half from New Haven to Tyler in Los Angeles (68-71). 
While Signals Newsbulletin contrasts with Duchamp's boxed set in terms of preciousness and detail, it possesses a similar logic of display. Duchamp described his project in the following manner: "Then I thought of the idea of the box in which all my works would be mounted like a small museum, a portable museum, so to speak" (qtd. in "Boîte-en-valise"). Keeler and Medalla's publication is a massmedia update for the post-modern era.

\section{The Art of Information Processing}

With the Newsbulletin, Signals becomes a galaxy of interwoven data. ${ }^{10}$ The operations of the magazine seem to parallel the shifts Marshall McLuhan saw occurring in other facets of society. The cybernetic theorist argues that: "When IBM discovered that it was not in the business of making office equipment or business machines, but that it was in the business of processing information, then it began to navigate with clear vision" (Essential McLuhan 151). Similarly, while not exactly in business, it appears that Medalla and Keeler's vision for their venture also involved the art of processing and repackaging information.

The Newsbulletin was an expansive project at the crux of various disciplines and genealogies. Demonstrating an impressive capacity for administration, Medalla secured permission to reprint articles from a diverse range of sources, such as the New Scientist, TIME, and a selection of dailies as well as more specialized texts laying out artistic ideas. Anthropological photographs of non-western people engaged in creative acts juxtaposed against vanguard art and science as well challenge received ideas about the difference between the "primitive" and modern (Fig. 3). Signals possessed the logic of a digest, archive, or anthology. Appropriating content from other sites and in a sense converting it into art discourse, Signals, in its published articles and images, served to enrich and illuminate the works reproduced - at times words illustrate images. Training constituents in a new kind of spectatorship, they further demonstrated that the divisions that exist between areas of thought and creative expression that are normally deemed unrelated could be more permeable. Especially for an informed, free-associating reader-viewer, the diverse elements seem to connect in myriad ways.

10 The McLuhanite idea of media galaxies surely influenced Medalla's thinking. His subsequent venture was an art space called Exploding Galaxy, seemingly a riff on McLuhan's Gutenberg Galaxy: The Making of Typographic Man (1962). 


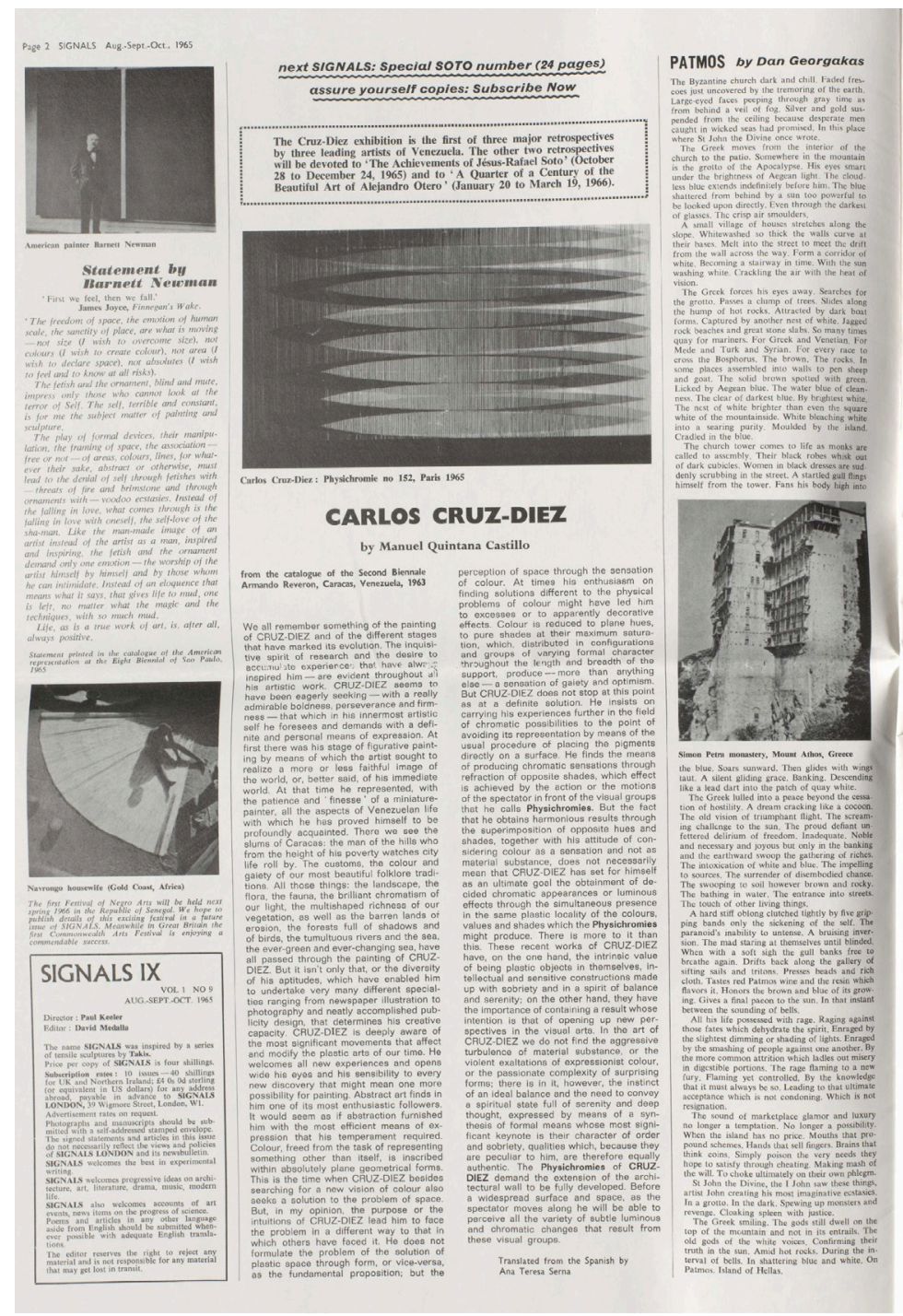

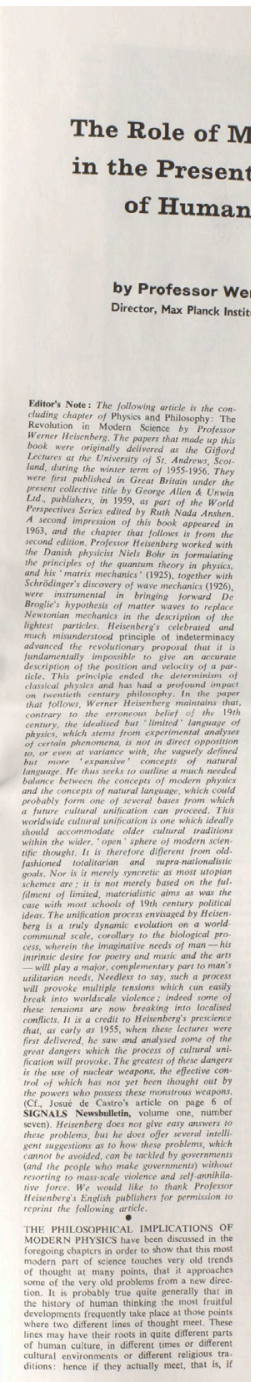

Fig. 3. Detail of Signals 1.10 (August-September-October, 1965), 2-3 with text and image of Barnett Newman, Navrongo housewife, a review of Cruz-Diez, and Werner Heisenberg's “The Role of Modern Physics in the Present Development of Human Thinking." (C) David Medalla and Paul Keeler. 
Music, art, poetry, and science could potentially cross - pollinate one another. Many covers render their art contents more scientific (or scientistic) and vice-versa. For number 5, Camargo's Wood Relief (1965) is juxtaposed against a small photo of cumulo-nimbus clouds. Each photo has an arrow signaling its respective caption, seeming to suggest that their resemblance was so uncanny that the scientific image could easily be confused with the art documentation. In the next issue, Marcelo Salvadori's circular shaped, plastic window installations appear with morphologically similar photographs of "the changing conditions of the sun" (Medalla, "Untitled," Signals 1. 6, 1). In this case, the solar logic was possibly catalyzed by the artist himself; he made a work titled The First Eclipse (1964), which is illustrated later in the issue. In the same number's interior, photos of Salvadori's Trace Project for Doors and Windows (1965) and a close-up image of a botanical specimen flank an article on Salvadori's work with polymers reprinted from the New Scientist.

Jesús Rafael Soto playing the guitar next to songs by Alasdair Clayre embodies interdisciplinarity of another stripe (Fig. 4). Indeed, it is difficult not to imagine him playing precisely the compositions that surround his photo. The image and text pairing extends the classical ut pictura poesis, a notion that is certainly important for Signals Gallery (which had a permanent collection of poetry books) and Newsbulletin too; here there is a suggestion that the artist can perform the role of the singer-songwriter and poet. With his guitar in hand, Soto becomes a folk singer-the most romantic figure in the landscape of the 60 s counter - culture - in the context of the broadsheet.

\section{Networked Multitudes: Virtual Curation and Collaboration}

Looking back on Medalla's career, the art historian Yve-Alain Bois affirms that the Signals editor produced artworks that operated with a certain kind of virtuality. Bois goes on to explain that he believes he saw very few of Medalla's biokinetic projects in the flesh; but, as a result of regular exposure to distribution of documentation, he felt familiar with the artist's oeuvre. Bois asserts, "his real performances were his narrations" (Bois 212). Hence, it was both the framing and the art action that constituted Medalla's artwork for the art historian. The same tendency that Bois identifies for Medalla's works equally extends to the diverse output that he selected for Signals: Newsbulletin.

Moreover, like with Duchamp's Boîte, Keeler and Medalla's embrace of multiplicity and moves to decentralize art did not entail an absolute rejection of materiality. Even while acting as "virtual" curator, Medalla certainly did not abandon an aesthetic and material sensibility. The paper's pages 


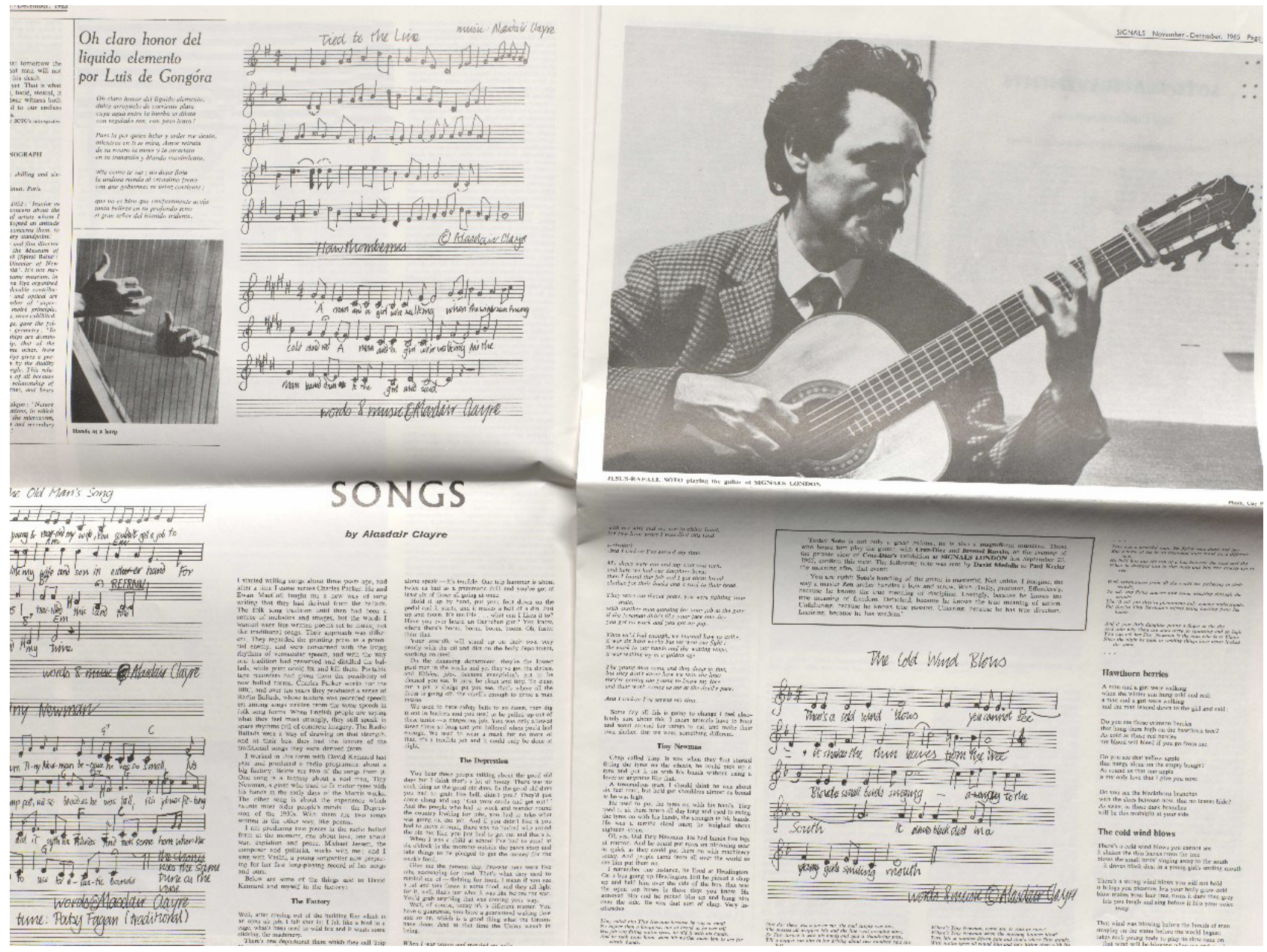

Fig. 4. Detail of Jesús Rafael Soto photo by Clay Perry in Signals 1.10 (November-December, 1965), 10-11. (C) David Medalla and Paul Keeler. 
are exercises in design as art as well as virtual display. Signals experimented with layout, graphics, different combinations of fonts, layouts, and boldly colored inks. Medalla's deliberate pairings of texts and images produce a range of new meanings and influence aesthetics. Signals Newsbulletin should be viewed as an instance of publishing as a form of art: a move aligning with conceptual artists' turn away from traditional artistic media toward the "aesthetics of administration" (Buchloh 105). Medalla's work as editor, layout designer, and curator might constitute an early form of conceptualism - a mode of making that privileges ideas over traditional aesthetics and materials. Indeed, Alexander Alberro reads many of the multiply produced works of conceptual art that would come only a few years later as a deviant form of publicity. Alberro argues that by employing "the infrastructure of publicity as medium," artists "problematized the traditional boundaries of artistic production" (152). He notes they both expand art and potentially bring it closer to commerce.

Form as well as content clearly mattered in the textual enterprise. Medalla had met a number of surrealist and beat poets in France and New York and was certainly aware of a longer trajectory of publishing developments related to concrete poetry. In the late $1950 \mathrm{~s}$ and $60 \mathrm{~s}$, poet William F. Burroughs and the painter, poet, and performer Brion Gysin revived Tristan Tzara's the poetic techniques of découpé (or cut-up) and developed their own method: "the fold in." The former involved new configurations of rearranged found materials; the latter, which Burroughs defined in 1961, consisted of "placing a page of one text folded down the middle on a page of another text (my own or someone else's). The composite text is read across half from one text and half from the other." In the 1970s Medalla created collage books that employ these tactics and bear a striking resemblance to Gysin and Burrough's The Third Mind (1978). Much like the poets' text-image project, Signals adapted the poetic techniques in order to meld a multitude of minds and disciplines. Thus, it both embraced the aesthetic possibilities of modern publishing and, via its poetic combinations of text and image, pushed back against what McLuhan saw as the homogenizing "visual logic of Gutenberg technology," which tended to render all it transmitted similar combinations of black signs on white ground. ${ }^{11}$

Working with many others - as both raw material and partners-Medalla artfully produced new creations. He danced a fine line between collaboration and appropriation. While Medalla was at the helm, Signals authorship was networked. Various voices speaking distinct verbal and visual languages supplement and supplant one another. Indeed, literary theorist Jacques Derrida's concept of the supplement quite aptly captures the modus operandi of the experimental periodical's contents.

11 McLuhan, The Gutenberg Galaxy, 136. In fact, McLuhan's (and Quentin Fiore's) layouts with text and found images in The Mechanical Bride and The Medium is the Massage reveal a similar logic to Medalla's. 
Derrida describes the supplement as "a plenitude enriching another plenitude" (Derrida 144). By layering and suturing disparate and related words and images, Signals enriched their meanings.

While Medalla certainly engineered many of the pairings, he did not direct all of the utterances he published. For instance, Duchamp's assessment of Takis ("gay laborer of magnetic fields and indicator of gentle railways") appears in large font among other articles (Signals 1.3/4 4). In the same issue, the potential for art and poetry to drive one another forward is made clear by a variety of homage poems: Gysin's “Magnetic Word-Music for Takis's Sculptures” (Signals 1.3/4 22), B. FarmanFarmaian's “Two Poems for Takis, Sculptor of Cosmic Light and Perpetual Forces" (Signals 1.3/4 15), and Alan Ansen, "A Poem for Takis" (Signals 1.3/4 12).

Color played an important role both in establishing the "Signals look" and enabling coproduction. A constant push and pull regarding authorship played out on the pages. Taking on the role of semi-authorized collaborator, Medalla boldly colored areas of photos of other artists' works. By tinting them with the sharp hues of "Swinging London," they arguably became more eye-catching. For instance, compared to the drab grey tones or garish rainbow inks of much "straight" art reporting of the time, Signals's striking signature design - black and white plus two colors-was extremely elegant. Signals was equally cool and countercultural: on the one hand, the bold text-image compositions recalled graphic design of the historic avant-gardes (the Bauhaus or INKhUK [Moscow Institute of Artistic Culture]); on the other, their dynamic-yet-limited color palette is similar to hip posters advertising rock concerts too. For instance, Soto and Otero's works in Signals 1, no 10 (November-December, 1965) and Signals 2, no 11 (January, February, March, 1966) respectively appear in stinging lemon and navy or acid pink and electric blue-color pairings found in contemporaneous ads for performances by British rock outfits as well as foreign musicians like Jimmie Hendrix or the Grateful Dead.

For example, in the Soto issue (1.10), the artist dominates the front page. There is a handwritten statement in French by the artist regarding the role of chance and movement in environmental art paired with the artist standing before his works with serial forms. Despite submitting some works to his designs, Medalla often respected the original hues in the artwork; he simply intensified them in his translations to Technicolor pulp. Yet, the blue and yellow inks are given further inflections by Medalla's front page publication of the "Korosta Katzina Song" of the Hopi Indians of Arizona, which describes yellow and blue butterflies. In a couple of cases Medalla's interventions verge on effacement. In the coloring of Grand Relation-Vibration, 24 black squares +24 Blue Squares (1965) and Grand Vibration-Relation: Blue and Black (1965), Medalla seems to turn the Venezuelan into a monochromist of the stripe of Yves Klein, famous for his trademark blue canvases. 
On the back cover of Signals's Soto special there is a color artwork, The Little Yellow (1965) (Fig. 5) that is not simply a colored photograph. Instead, a square of electric yellow appears about a black square nested in a series of regular black lines imprinted on the glossy stock. Because there is not a photo suggesting another deferred location, the printed page becomes the direct site of interface. The Little Yellow is presented in the magazine, rather than illustrated in it. Right above the work and to its left are a blurb from Charles Spencer's New York Times review of Keeler's Soto show and an announcement of the exhibition with the Signals Gallery addressin a sense illustrating the work shown in the Newsbulletin. These articles serve a provocative function: they conjure up an image of the Soto show in a brick-and-mortar place, removed from the space of the page. Nonetheless, the mass distributed cellulose support actually expands the exhibition beyond the gallery. Because of The Little Yellow's material qualities, there is a sense that a little bit of the show is now in the hands of the reader-beholder.

A grid of 20 Soto signatures appears above the crease on the same page as The Little Yellow. When folded down these repeated assertions of the presence and authority of the artist caress the nested squares. The Soto signatures are more complex than simply stamps of authenticity or claims to territory. Anticipating Belgian conceptualist Marcel Broodthaers's repeated initialing of "M.B." in his screenprint

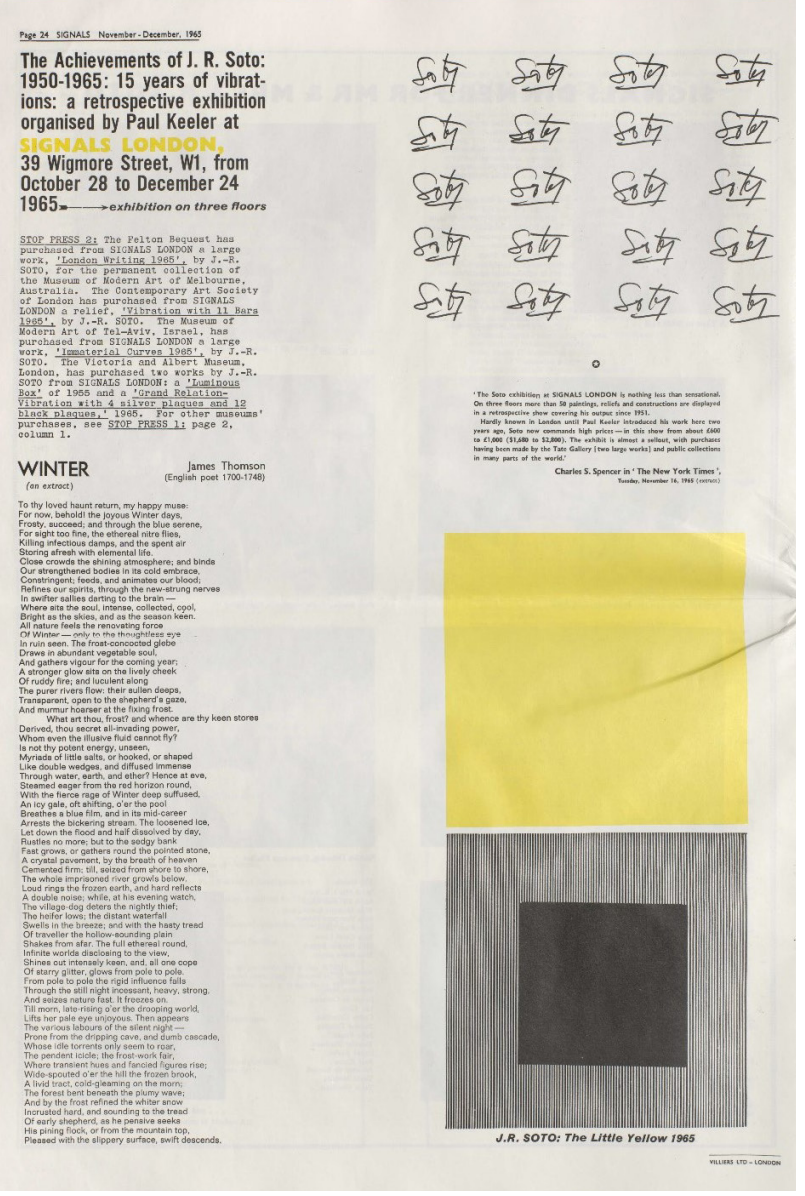

Fig. 5. Back cover of Signals 1.10 (November-December, 1965), 24 with Jesús Rafael Soto, The Little Yellow, 1965. (C) David Medalla and Paul Keeler; (C) Jesús Rafael Soto. 
La Signature, Serie 1. Tirage illimite (1969) (Fig. 6), the multitude of Sotos are also printed on the page via a process of mechanical reproduction. Each is slightly different, but their individuality is only perceptible with close study. While the names could seem like an over-determined assertion of the authorial presence, singular authorship is a shaky proposition with the Newsbulletin. The process must have been collaborative; at the least, Medalla would have had to request the autographs - a simultaneous act of collection, homage, and certification. Repetition hollows out the sign, turning it from unique, hand-made, marker of authorial authority into a serial pattern - which is subsequently lithographically reproduced ever more times. The composition employs the mark of artistic authenticity to interrogate art. On the broadsheet, the Soto signature becomes a readymade design, just one more ordered configuration of information. In an inversion of Burroughs's method, it is by folding out the entire recto that the beholder reveals the Newsbulletin's poetry: it is clear the signatures rhyme with the layout elements on the front page. Hence, the back and front together both celebrate and undercut the cult of the artist genius (Fig. 7).

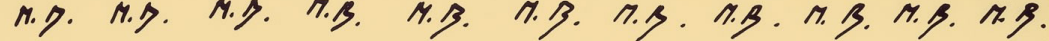

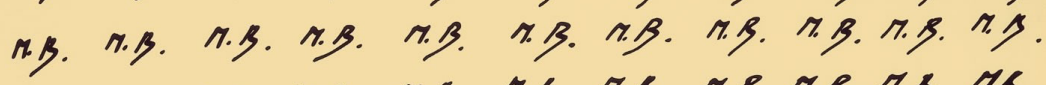
M.g. M.S. M.S. M.S. M.S. M.S. M.S. M.S. M.S. M.S. M.S.

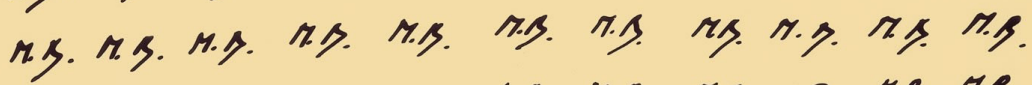

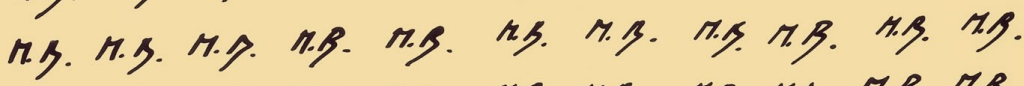

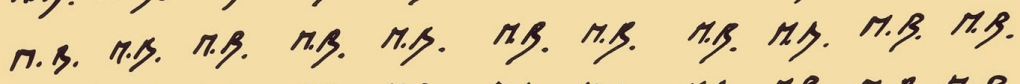

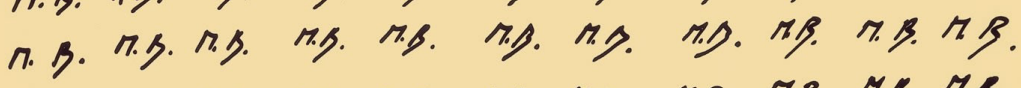

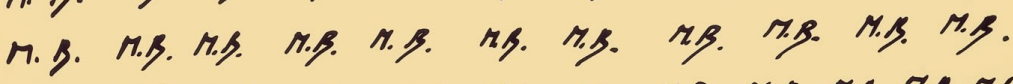

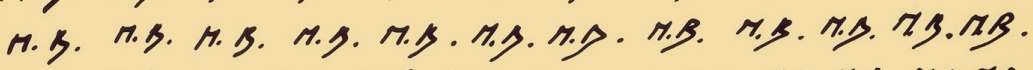

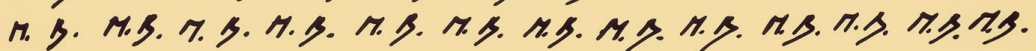

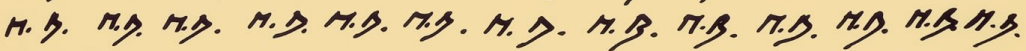

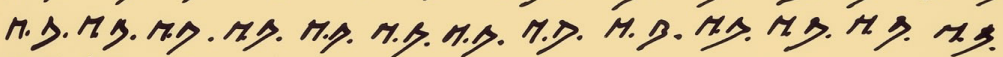

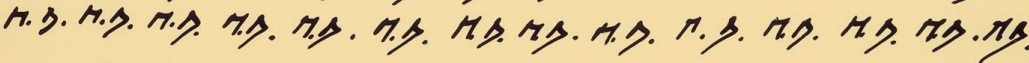
- La Signatare Séric 1. Tirage rllimité.
Fig. 6. Marcel Broodthaers, $\mathrm{La}$ Signature, Serie 1. Tirage illimité, 1969. Silkscreen on paper. (C) Marcel Broodthaers. 


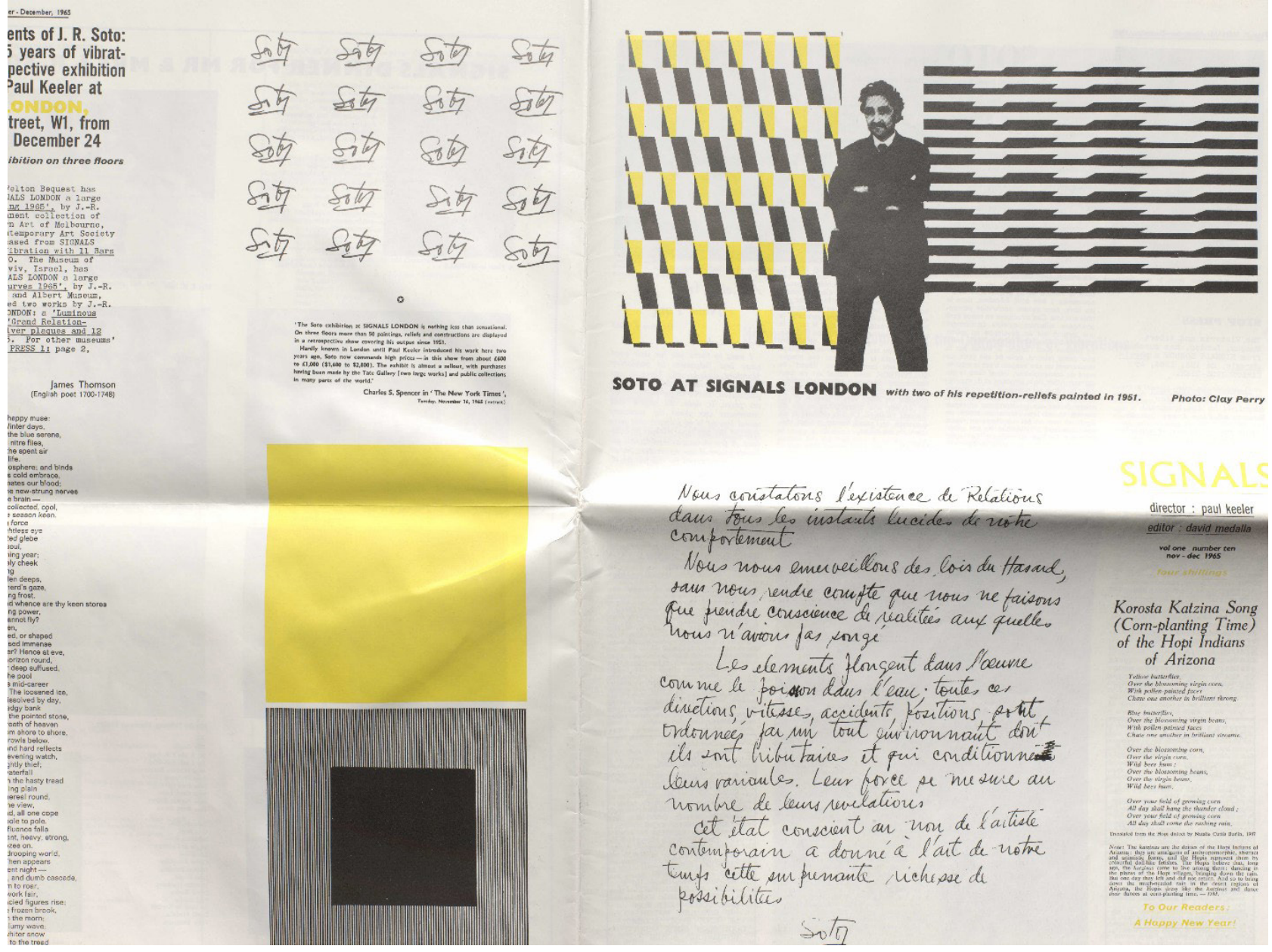

Fig. 7. Detail of front and back covers folded out of Signals 1.10 (November-December, 1965). . (C) David Medalla and Paul Keeler; (C) Jesús Rafael Soto. 
However, the existence of the principle colors in each monographic edition operates as a kind of branding exercise as well. In the Otero issue (2.11 [Jan, Feb, March, 1966]), pink and blue does not just mark Medalla's hand in the process. They also become shorthand for the entirety of Otero's artistic identity. While Otero worked in a wide range of colors and materials, pink and blue do appear at various moments in his output. In Signals, the colors dominate 49 por ciento (1965), a painted newspaper on wood artwork that graces the journal's cover (Fig. 8). As it runs without any text above the fold (a deviation from nearly all other issues of Signals), Otero's artwork-itself made of titles, ads and articles - becomes the headline. The composition furthermore yields a kind of mise-en-abyme effect when printed on broadsheet paper. This effect might cause a short circuit for Anglophone readers, for whom the content of Otero's work was a foreign pattern instead of legible signals. Here, due to scale, and Otero's employment of the news media as medium, the printed version of the work possesses a directness normally experienced with art encounters in a gallery.

The same blue and pink of 49 por ciento also appear in the titles and author names running through the entire number. The pair of hues imply that Otero's influence colors the surrounding elements of the news bulletin, which is equally true for each issue's protagonist. Below Otero's front-page artwork, Medalla reproduces an excerpt from William Shakespeare's Troilus and

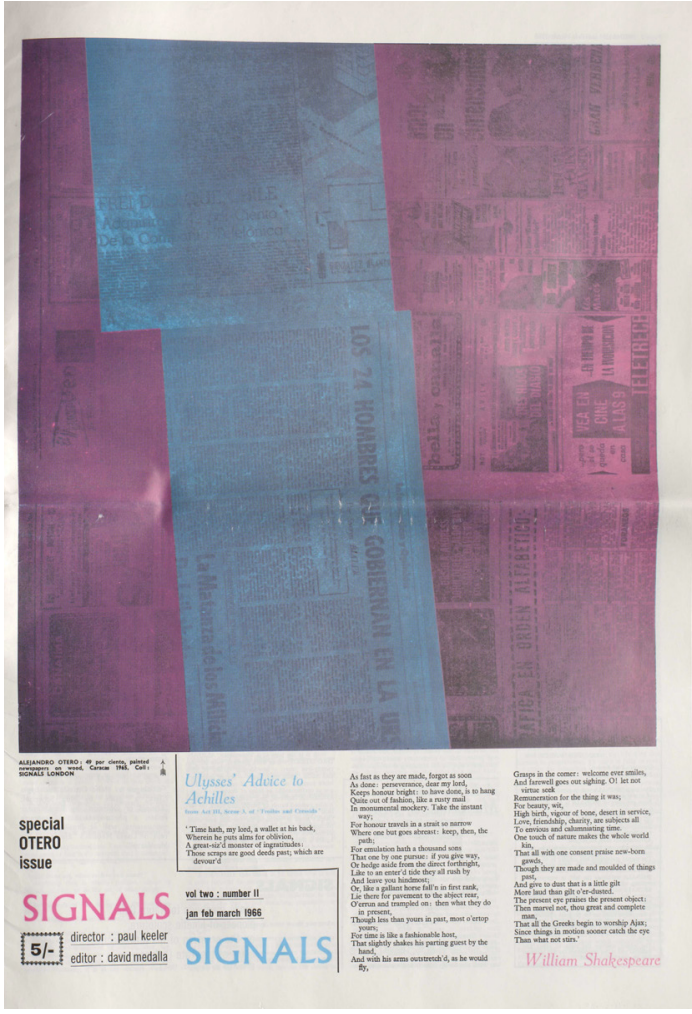

Fig. 8. Front cover of Signals 2.11 (January, February, March, 1966) with Alejandro Otero 49 por ciento, 1965. (C) David Medalla and Paul Keeler; (C) Alejandro Otero. 
Cressida (Act III, Scene 3) discussing time, motion, and impermanence. The title, "Ulysses' Advice to Achilles," and citation information appear in the electric azure ink and the bard's name is pronounced in the bubblegum pink. Thus, not only is England's foremost author marshalled to help the international readership understand Otero, but Shakespeare and his anglicized Greek characters too experience a slight expatriation. When made to relate to the artist's work, they become a bit more Latin American. The seventeenth-century words literally_and figuratively - take on the same tint as the Venezuelan's artwork. The choice to caption contemporary art with Shakespeare may seem peculiar or esoteric by today's standards. However, quotes from his plays pepper McLuhan's writing (something to be expected from a professor of English) on media and would not have seemed out of place to period viewers who had cut their teeth on popular cybernetics. In Understanding Media (1964), he argues: "Troilus and Cressida $[\ldots]$ is almost completely devoted to both a psychic and social study of communication" (24).

\section{Adventures in Networking}

As well as gathering interdisciplinary content, Signals Newsbulletin propagated the activities around Signals Gallery as well as the exhibitions held inside it. Fulfilling a role a bit like "Scene and Herd" in today's Artforum.com, the paper traced the social network that crystallized around the gallery and their stable. Because it could be seen to yield an imagined community of readers, the paper produced this network too. The publication was part newsletter and part society page. It made an inexpensive gift or souvenir with which to link in new contributors, sponsors, or (though not a major concern) buyers and catalyze memories of the gallery.

Nearly every issue includes "thanks yous" to donors, salutations, reports on attendance. Their list of private patrons was quite impressive. Aware of the potential to attract future sponsors and further augment their own prestige, donors - including a number with noble titles - appear on the front page. This presentation recalls the way many museums list trustees at the front entrance. By the eighth issue, Caresse Crosby, inventor of the modern bra and an important patron of progressive arts initiatives on both sides of the Atlantic was at the front of the list. ${ }^{12}$ Others recognized hailed from the art world, including Mrs. H. D. Molesworth (Eve Galloway), wife of the keeper of sculpture at the Victoria \& Albert; Sir John Rothstein, director of the Tate; the British surrealist, Roland Penrose; the champion

12 Crosby helped run the G Place Gallery in Washington, D.C. This gallery was important venue for showing the work of African-American artists: for instance, Romare Bearden's second solo show was held there in 1945. 
of kineticism, art historian and curator Frank Popper; and the painter Frank Avray Wilson. The names of Keeler's parents, who paid for the building and shouldered many of the costs of the Newsbulletin, follow Sir Robert and Lady Mayer, philanthropists best known for supporting musical programs for children. Guy Brett's parents_-Vicount and Viscountess Esher-were also sponsors.

In an almost ingenuous fashion, Medalla dropped the names of visitors to Signals or notable people who had corresponded with them. For instance, sharing the page of issue 11 with Haacke's letter, are acknowledgements and thanks offered to Nina Gabo, the daughter of the famed constructivist (Naum Gabo), "for providing contact with Mr. Lewis Mumford," the important architectural critic. ${ }^{13}$ The text continues, detailing a chain of connections, "The Editor thanks Mr. Lewis Mumford for sending over from New York a transcript of his address to the American Academy of Arts and Letters and a Photostat of the letter from the poet Robert Lowell to President Lyndon B. Johnson."14 The editors extend congratulations to Naum Gabo for his solo exhibition at the Tate alongside letters by Kepes and Dore Ashton. Demonstrating a certain degree of ironic self-awareness, in issue 3/4 the title "Name Dropping" appeared just below a list of Signals's collaborators; it actually corresponded to a section discussing the decision to stop using the "mouthful" of a name, Centre for Advanced Creative Study, Name Dropping. In one case, they ran a photo shoot documenting a dinner held for Jesús Rafael Soto, complete with a guest list. This type of exclusive event is typically solely for insiders: the artists represented by the gallery, possible buyers, or critics. Not quite gossip, the lists of names and photos of artist-celebrities private moments, augment the glamour of Signals. Moreover, rather like the logic of citations in academic writing, the multitude of proper names invoked provides authority for the gallery and its contents.

With the exception of announcements for shows at other galleries and museums - often featuring artists to whom they were sympathetic, Signals was free of advertising. How closely "curated" the ads were however, is unclear. The magazine included an advisement for its own ad space in issue 3/4. Another notable, apparently paid announcement ran in the tenth issue: it heralded the opening of the countercultural bookshop and art gallery INDICA. Of course, in many ways the paper was an elaborate advertisement for the exhibitions and artists shown at the gallery. For example in the issues on Carlos Cruz-Diez and Sergio de Camargo, the dates of their shows are clearly stated. In Camargo's case, his prior accolades and the copy "first-one man show in Europe"-perhaps recalling a film poster or performance - seem to slide his work toward the realm of the culture industry.

13 See Signals 2, no 11 (January-February-March, 1966): 15

14 Ibid. 
We can equally view Signals Newsbulletin as a venture not just in publicity but as widely disseminated and advancing developments new art. Certainly, the projects the publication promoted were not typical commodities. According to Medalla and Keeler's statements in Signalz 1.1, "Signals London is a nonprofit organization dedicated to the adventures of the modern spirit." The slogan was emblazoned on the front pages of issues three/four and five. They lived up to their goal and the gallery did not provide them with any commercial windfall. Surely it served as a form of what would today be called "networking," augmenting the young men's social capital (six years later Lawrence Alloway would analyze art and its institutions this way in "Network: The Art World Described as a System"). Medalla and Keeler's enterprise employed strategies of capitalist promotion and distribution to "sell" a different kind of product, knowledge and art experience that was ideally free and open to anyone who visited 38 Wigmore Street or picked up the Newsbulletin.

\section{Returns and Revolutions: From Cold War to Hot War and the End of Signals}

The expression of various generations of the avant-garde were woven together in a collage of word and image in Signals; these juxtapositions served a historicizing function, setting the contemporary works of the signals artists into a common genealogy with modern "masters." Perhaps most clearly demonstrated by a special Gabo issue (Signals 1.8), Signals connected the historic avantgarde with that of the present. For instance, re-contextualized in the journal (April-May, 1965), Lygia Clark's Architecture Fantastique transforms into a monstrous, monumental construction, recalling the stabiles of Alexander Calder, a relationship that Signals also proposes in issue 8; in the same issue, Brancusi appears along with a collage by Medalla recalling a work by Lissitsky. In the Soto issue Medalla translates the Venezuelan artist's output into a form of "simple arithmetic," or as he also dubs it, "Signs": - Malevich + Mondrian = Soto (Signals 1.10 21). Keeler's exhibition Soundings Two multiplied these connections in the gallery space: artworks by Albers, Brancusi, Calder, Duchamp, Moholy, Lissitsky, and Malevich were exhibited alongside those of Clark, Soto, Helio Oiticica, Mira Schendel and Medalla. Achieving similar results by scaling, Signals 8, presents equally sized photos documenting sculptural works to establish a relationship between Medalla and Kurt Schwitters.

In issue 2 Medalla wedded his own work to fragments of poetry by Venezuelan poet Roberto Ganzó that were originally penned in French, but here translated into Ganzó's native tongue. The poems had initially had a career accompanying works by the modern artist Ferdinand Leger. Hence, by amending the same text but in Spanish, Medalla suggests there is a parity of the images appended: his 
work, though more Southern, belongs in a lineage with Leger. Also in the second number Medalla ran words of Vladimir Mayakovsky alongside his work: "If you like I shall grow/ irreproachably gentle/ not a man, but a cloud/ in trousers ..." (Signals 1.2 8) (Fig. 9). The late Soviet poet had collaborated with Alexandr Rodchenko during the 1920s, composing slogans to accompany the Russian artist's designs. Hence, by pairing his poetry with documentation of Medalla's biokinetic foam sculptures, they again acquired a radical inflection.

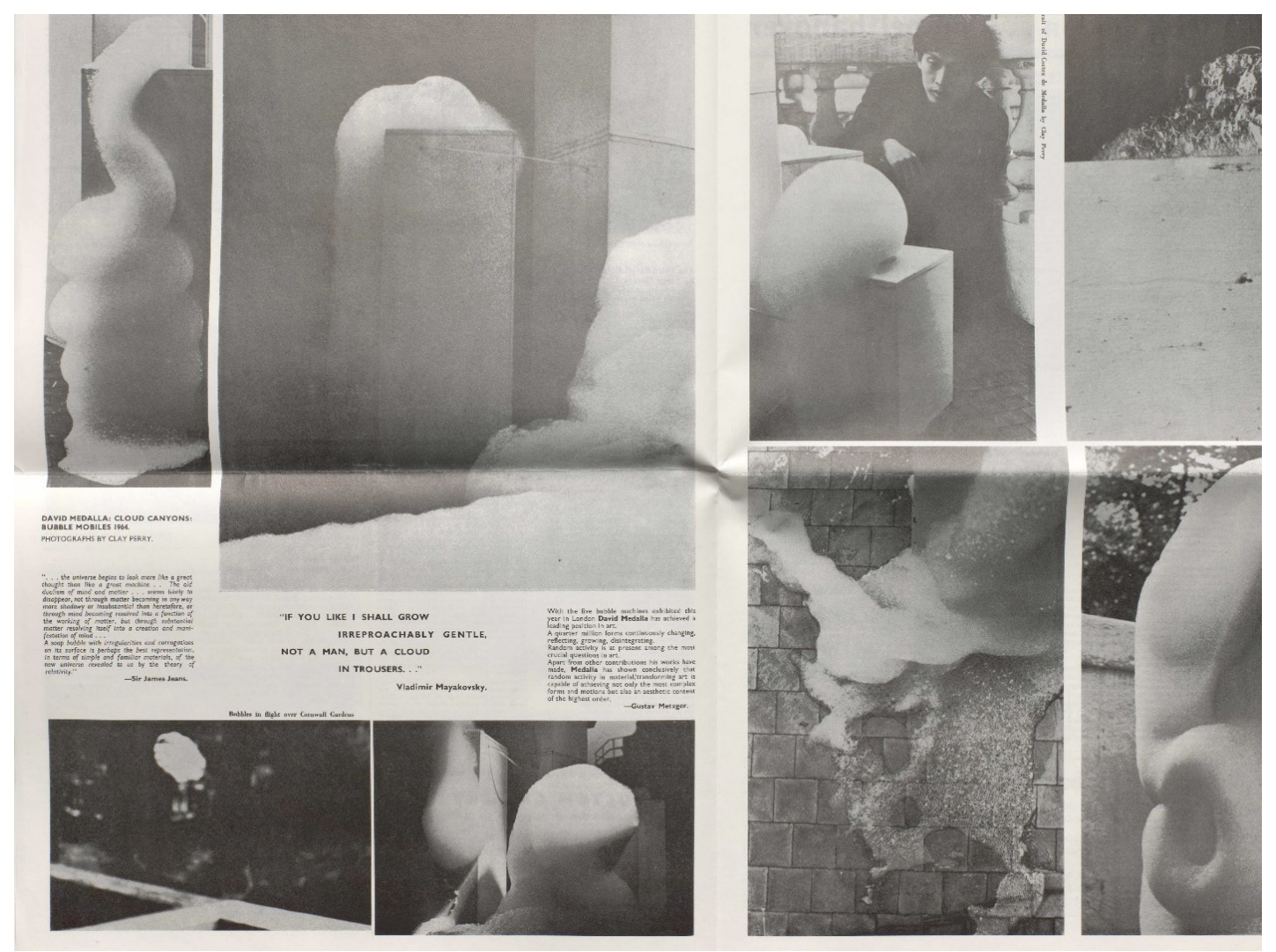

Fig. 9. Medalla Cloud Canyon images in Signals 1.2 (September, 1964), 8. C David Medalla and Paul Keeler. 
Importantly, this valence of radicalism continued in the design: Signals' bold duo-chrome design plus dynamic text seems to owe something to early Soviet advertising and posters. A number of the projects that Mayakovsky and Rodchenko worked on together rely on the same formula - albeit almost always with the crimson of the USSR and not the psychedelic colors of 60 s London. Hence, by citing revolutionary poets and emulating revolutionary design, Signals's project both connected to historic constructivism and the revolutionary promise of the early U.S.S.R.- - before purges, gulags, repression, and scarcity came to characterize the communist polity.

In the Gabo issue, Medalla rebrands an image of men laboring on a pylon with signs reading "Signals" and "London" (Fig. 10). Sending mixed and doubled signals, he amended the following caption: "david medalla: found-foto (SEÑALES LONDRES) $1965 \bullet$ " While Medalla effectively used the surrealist technique of the objet trouvé, the particular picture he encountered, when paired with text, recalls Lissitsky's Lenin Tribute (1920) (Fig. 11), which shows the Soviet leader at the top of a similar structure (in terms of form and color) with text on a sign. However, rather than just suggest Signals is the amplifier of the constructivist inheritors of Russian avant-garde art, his label performs a more complex maneuver: it translates the revolution into Spanish, the language of Latin America.

According to Carlos Cruz-Diez, Latin American art in the 60s possessed a similar radical, revolutionary charge as Russian Constructivism. When asked by art critic Ariel Jiménez about Signals, the artist proposed a link between vanguard art and revolution:

Why Russian Constructivism? [...] A revolution took place in Russia, and [...] a great many artists saw that revolution as an exceptional constellation of historic events that demanded a radically new form of art [...] the same thing happened with Latin America. It was an explosion, and Latin America was exceptionally validated with the triumph of the Cuban Revolution. This marked a critical juncture in time which the planet took notice of the continent (Cruz-Diez qtd. in Cruz-Diez and Jiménez 71).

On the pages of the magazine Medalla helps to crystallize a "fourth international" of art. The resolution of art and science as creativity the publication engenders as well might be viewed as an update of Karl Marx's affirmation: "We recognize only one science, the science of history." Confounding (and conflating) North-South and East-West divisions, Signals flaunts the binaries of the Cold War era globe.

It was their stance on the hot war in Vietnam, however, that led to Gallery and Newsbulletin's demise. Medalla reproduced Lewis Mumford and Robert Lowell's respective critiques of Lyndon 


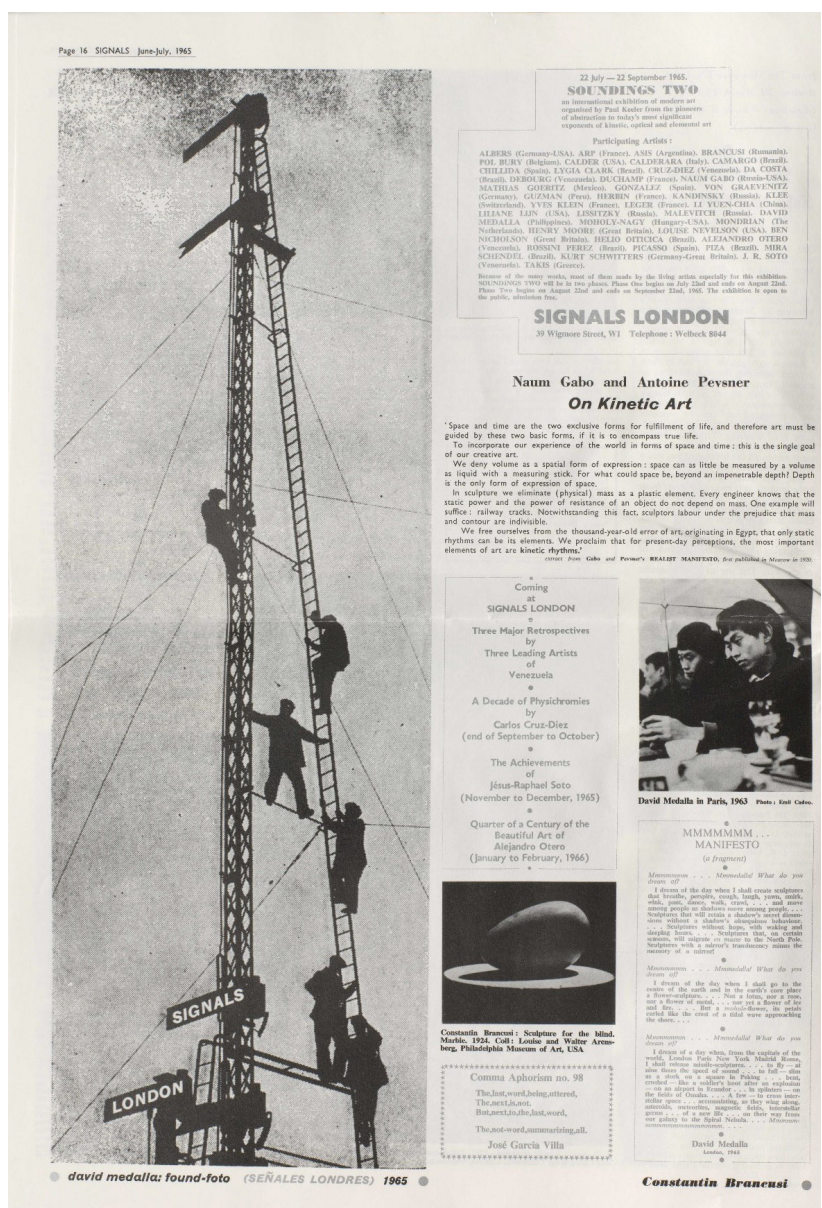

Fig. 10. Back cover of Signals 1.8 (June-July, 1965). C David Medalla and Paul Keeler.

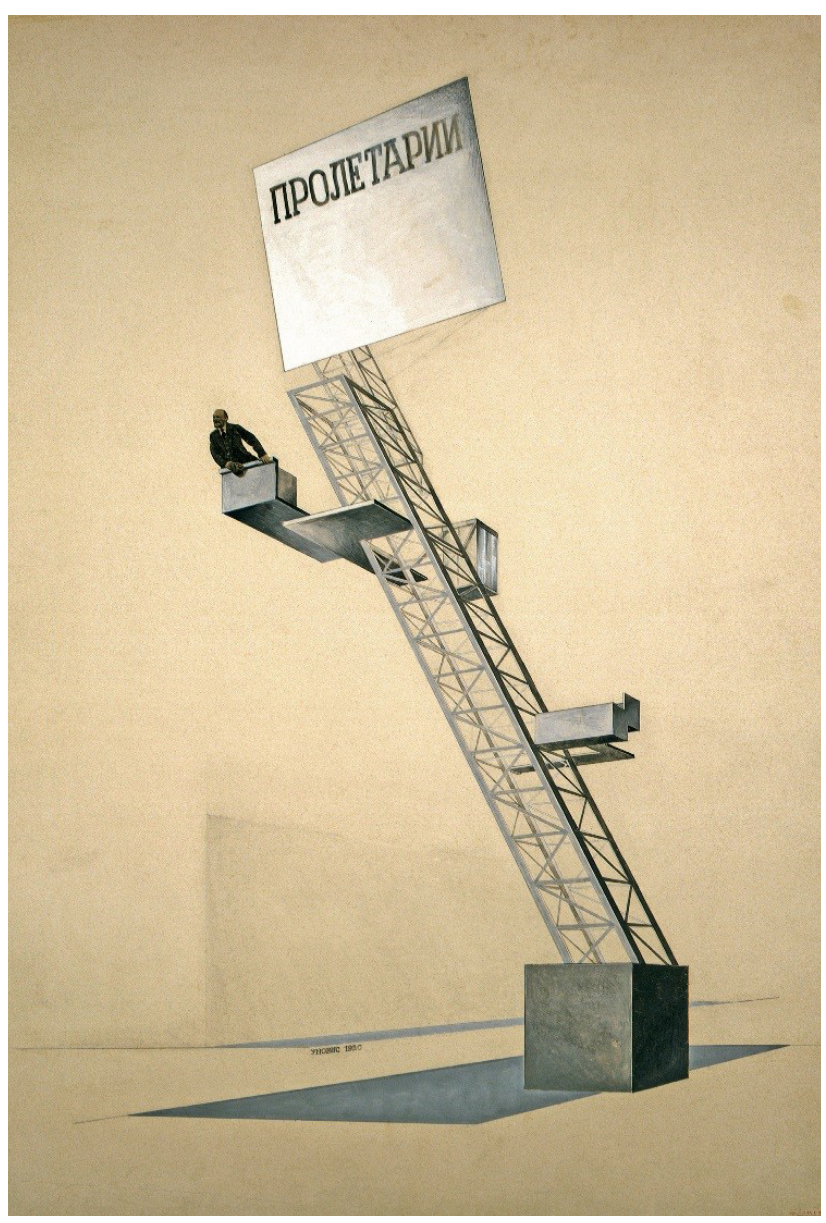

Fig. 11. El Lissitzky, Lenin Tribune Proposal, 1920, gouache, india ink, and photomontage on cardboard, $63.8 \times 48 \mathrm{~cm}$. 
Johnson's foreign policy in their entirety (1.8 [June-July, 1965]). Their primary financial backer, Charles Keeler, Sr., understood these reprinted missives not as harmless citations, but as incitement against the proper order of things. A conservative with a strong business acumen, the senior Keeler disapproved of the critiques of the Vietnam War republished in the art journal. Nevertheless, his officially cited reason for concluding his financial support of the textual enterprise and gallery was their lack of commercial viability. The final issue of the Newsbulletin came out in January of 1966 and the Gallery's last exhibition was held in September of the same year. Both Keeler and Medalla, as well as many of the other artists Signals broadcast, would continue to enjoy successful careers.

\section{Found Poems, Lasting Transmissions}

In a number of issues of Signals Medalla composed poems dedicated to other artists. Two of the most provocative ran with the title "found poem." As their name suggests, these consisted of fragments of other images and texts that the artist-publisher encountered. He intervened in them, adding a personal touch with his own hand-written notations and dedication. The act of composition as homage is a tendency that courses throughout Medalla's printed output. This form of empathetic, intersubjective, artistic production particularly characterizes his poetry in Signals. In his poem-like "Stele to Takis" (1961), Medalla appears to have taken a similar approach: it is a composition with found language.

"Found-Poem for Otero" is a fragment that pairs a series of line-drawn tools and their names (Fig. 12). Rows with variations of trowels, cleaners, and smoothers become rhyming stanzas when reframed as poetry. The seemingly tautological diagram recalls Otero's collage reliefs, projects which saw the artist affixing tools to wooden planes. Medalla's text-image is a cipher for the Venezuelan's works. Paralleling his shift of the everyday into poetry, Otero, in this artistic act, removes their use value and prompted them to become artistic signs; according to critic Jonathan Bell the artist discovered "the unknown in the obvious" (Bell 12).

Medalla's image-poem seems to epitomize Americanist George Kubler's notions about form laid out in The Shape of Time (1962). At the cutting edge of period thought, Kubler rejected authorshipbased art history and emphasized the need to view expressions of culture as linguistic utterances. The Yale professor importantly begins his study by proposing an expansion of "art" to encompass "the whole range of man-made things, including all tools and writing in addition to the useless, 


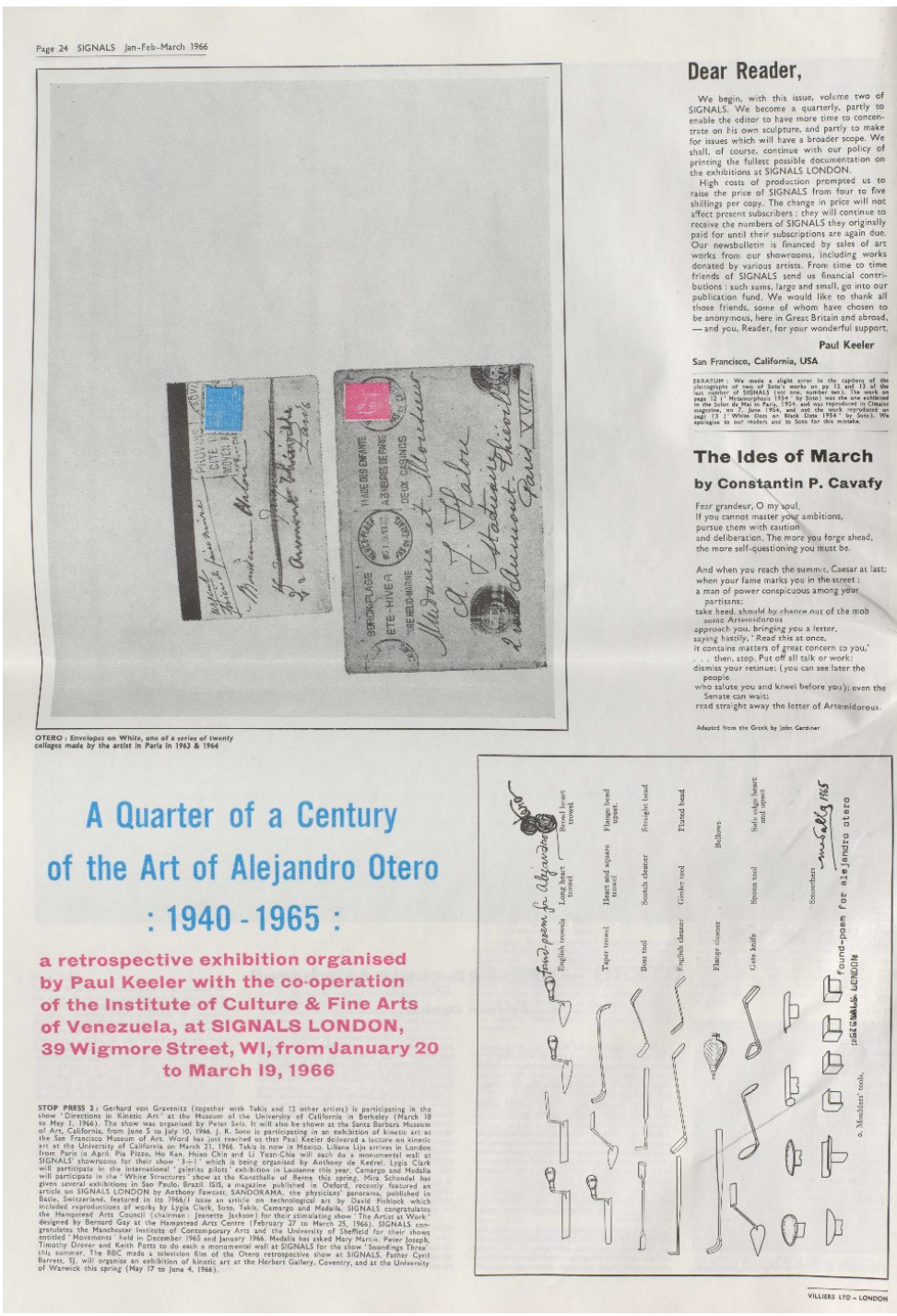

Fig. 12. Detail of David Medalla, "Found-Poem for Otero," Signals 2.11 (January, February, March, 1966), 24. (C) David Medalla and Paul Keeler. 
beautiful, and poetic things of the world" (Kubler 1). Indeed, capturing ideas of transmission, Kubler discusses art in relation to "signals" in the book's framing chapters. Moreover, a mere ten pages into the tome, we find him discussing art-science connections.

Especially given his early interests in ethnography and the material culture of indigenous peoples in the Philippines, it seems very likely Medalla would have been familiar with Kubler's text. Kubler's book was de rigueur in New York art circles. John Baldessari created Painting for Kubler (1968); Robert Smithson channeled the Americanist's ideas as well in his November 1966 Arts Magazine project, "Quasi-Infinities and the Waning of Space," an artwork-article that combines diagrams, text, and images in a mode reminiscent of Signals.

Medalla is responsible for the two elements on the back page of the April-May, 1965 issue. In the top half of the sheet there is a close up of Medalla's Cloud Canyon (1964). Below it, is his "Found Poem for Takis" (Fig. 13). The "Found Poem" combines a diagram of celestial signs with a mosaic of nearly 120 alphabetized words - many related to the war in Vietnam, the Cold War, and information technology. The poem is transmitted by ink in the metallic copper hue that is the "theme color" of the issue as well as the standard midnight black. The text-based work blends conceptualism and performance. A box with text prompts the reader-viewers to penetrate the pages and sends them to From the Editor's Desk. This other site in the publication outlines the rules of the game: in order to produce the poetry, the words should be alighted upon in the manner of a Ouija board game.

Medalla makes pedagogical points with his poem. It proves how fields of language and ideas thread through one another. Moving though the nearly 120 terms - including "advance," "aircraft," "ammunition," "arc of observation," "casualty/ casualties," "guided weapon," "own troops,"- this work very much speaks to the bellicose realities of the era; but, by appropriating them for poetic performance sends them in new ludic directions. Engaging in a tabletop finger scale choreography with the paper, reader/poets interpreted and composed Medalla's text, becoming co-authors of sorts. The poem could be viewed as an extended caption for his adjoining sudsy project. Like the soapy tech art, the found poem fulfills Herbert Marcuse's call for "a science and technology released from their service to destruction and exploitation, and thus free for liberating exigencies of the imagination" (Essay on Liberation 31). Moreover, there is a suggestion that the poem is of equivalent value to Medalla's ever expanding, ephemeral, irregular kinetic foam sculpture reproduced above it.

Looking back at the history of what she called "dematerialization" of art, the critic Lucy Lippard argued that the important shift away from physical objects in galleries towards more conceptual 


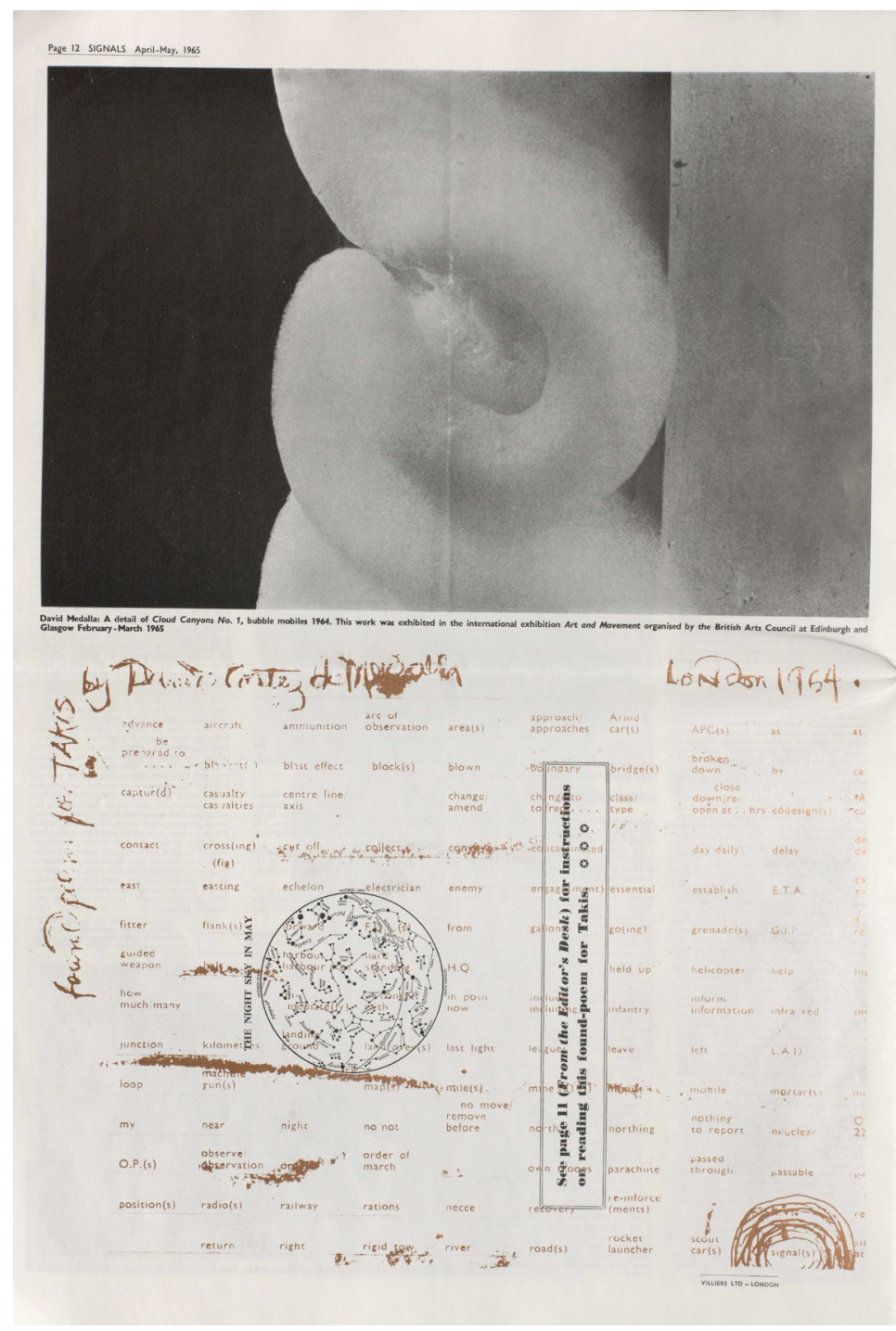

Fig. 13. David Medalla, "FoundPoem for Takis," Signals 1.7 (AprilMay, 1965), 12. (C) David Medalla and Paul Keeler. 
projects in which art took the form of decentralized information began in c.1966: the year Signals dissolved. Art as signals - moving towards data rather than things - was to become the next vanguard. The publication confounded bounds between representation and reality, potentially expanding the production of art far beyond brick-and-mortar institutions.

According to Guy Brett, Medalla's key contribution as artist was his works's tendency to encourage audience participation. This quality extends to Signals, which enabled audience interaction as well; the "Found Poem for Takis" marks its zenith. Crossing borders between past and present, this playful poem can still conjure up memories of the era and be completed by readers today. The process of composing the poem prompts the reader-viewer to become biokinetic performer-fulfilling Medalla's goals of producing a living art even more successfully than the Cloud Canyon above it. When pulled off the library shelf, Signals's appropriations continue to hold the potential for turning on and tuning in contemporary collaborators. 


\section{Works Cited}

ALBERRO, Alexander. Conceptual Art and the Politics of Publicity. Cambridge: MIT Press, 2003.

ALLEN, Gwen. Artists' Magazines: An Alternative Space for Art. Cambridge: MIT Press, 2011.

ALLOWAY, Lawrence. "Network: The Art World Described as a System," Artforum 11, no. 1 (September, 1972): 28-33.

BELL, Jonathan. "The Unknown in the Obvious: The Art of Alejandro Otero." Signals 2.11 (January-FebruaryMarch, 1966): 12-13.

BOIS, Yve-Alain Bois. "Virtual." in Guy Brett. Exploding Galaxies. London: Kala Press, 1995, 212.

"Boîte-en-valise," NGA Australia http://nga.gov.au/international/catalogue/Detail.cfm?IRN=64922

BRETT, Guy. Exploding Galaxies: The Art of David Medalla. London: Kala Press, 1995.

BUCHLOH, Benjamin. "Conceptual Art: From the Aesthetic of Administration to the Critique of Institutions." October 55 (Winter 1990): 105- 43.

BURROUGHS, William. "The Cut Up Method.” In Leroi Jones, ed., The Moderns: An Anthology of New Writing in America. New York: Corinth Books, 1963.

COCKCROFT, Eva. "Abstract Expressionism, Weapon of the Cold War." Artforum 15, no. 10 (June 1974): 39-41.

CRUZ-DIEZ, Carlos. "Photo-Strip Cruz-Diez," Signals 1.9 (August-September-October, 1965), 5,6, 9, 11.

CRUZ-DIEZ, Carlos and Ariel Jiménez. Carlos Cruz-Diez in Conversation with Ariel Jiménez/ Carlos CruzDiez en conversación con Ariel Jiménez. New York: Fundación Cisneros/Colección Patricia Phelps de Cisneros; bilingual edition, 2010.

DERRIDA, Jacques. Of Grammatology. Translated by Gayatri Chakravorty Spivak. Baltimore: John Hopkins University Press, 1967.

FOX, James. "From North to South.” The Observer 8.VIII (1965), reprinted in Signals 1.9 (August-SeptemberOctober, 1965): 16.

FRIED, Michael. "Art and Objecthood." Artforum 5, no. 3 (June 1967): 12-23.

"Great Britain: You Can Walk Across It On the Grass." TIME, Friday, Apr. 15, 1966, online. http://web.a.ebscohost. com.proxygw.wrlc.org/ehost/detail/detail?vid=11\&sid=2b8f1c36-13a5-44bc-8119-4e8cc1d2a4b8\%40s essionmgr4005\&hid=4104\&bdata=JnNpdGU9ZWhvc3QtbGl2ZQ\%3d\%3d\#AN=54033701\&db=a9h.

GREENBERG, Clement. Art and Culture: Critical Essays. Beacon Press: Boston, 1961.

HOGARTH, Paul and Malcolm Muggeridge. London à la Mode. London: Studio Vista Limited, 1966.

KEELER, Paul and David Medalla. "Signalz, Signalz, Signalz, Signalz," Signalz 1.1 (August, 1964): 1.

KELLNER, David, ed." In Art and Liberation: Collected Papers of Herbert Marcuse, Vol. 4. New York and Oxon: Routledge, 2007.

KOZLOFF, Max. "American Painting during the Cold War." Artforum 11 (May 1973): 43-54

KUBLER, George. The Shape of Time: Remarks on the History of Things. New Haven: Yale University Press, 1962.

LEE, Pam. Chronophobia: On Time in the Arts of the 1960s. Cambridge: MIT Press, 2004.

LIPPARD, Lucy. Six Years Six Years: The Dematerialization of the Art Object from 1966 to 1972. Berkeley and Los Angeles: University of California Press, 1973.

MARX, Karl. "Excerpts from The German Ideology (1845).” Marxists.org. https://www.marxists.org/archive/ marx/works/1845/german-ideology/ch01a.htm. 
MARCUSE, Herbert. An Essay on Liberation. Boston: Beacon Press, 1969.

MCLUHAN, Marshall. Understanding Media: The Extensions of Man. New York: Signet, 1964.

The Gutenberg Galaxy: The Making of Typographic Man. Toronto University of

Toronto Press, 1962.

1995.

MEDALLA, David. "Name Dropping.” Signals 1.3/4 (October-November, 1964), 24.

"Found-Poem for Otero." Signals 2.11 (January-February-March, 1966): 24.

"Found Poem for Takis." Signals 1.7 (April-May, 1965): 12.

SIGNS: From David Medalla's Notebook 'On Simple Arithmetic' (1965)." Signals Newsbulletin 1.10 (November-December, 1965): 21. "Untitled." Signals 1.6 (February-March, 1965): 1.

MITCHISON, Amanda. "The Bubble Reputation." The Independent. February 3, 1995. http://www.independent. co.uk/life-style/the-bubble-reputation-1571468.html

MoMA. “TECHNICS AND CREATIVITY: SELECTIONS FROM GEMINI G.E.L.” May 5, 1971. https://www. moma.org/momaorg/shared/pdfs/docs/press_archives/4623/releases/MOMA_1971_0060_43.pdf?2010.

NANKERVIS, Adam. "A Stitch in Time." Mousse. http://moussemagazine.it/articolo.mm?id=707.

NANKERVIS, Adam. "David Medalla - Cloud Canyons." Another Vacant Space (November, 2011). http://www. anothervacantspace.com/David-Medalla-Cloud-Canyons.

PLANTE, Isabel. "Les Sud-américains de Paris. Latin American Artists and Cultural Resistance in Robho Magazine," Third Text 24, no. 4 (July 2010): 445-455.

"Search results for 'signals: Newsbulletin'." Worldcat.org. http://www.worldcat.org/search?q=signals\%3A+New sbulletin\&qt=results page.

SNOW, Charles P. The Two Cultures. London: Cambridge University Press, 1959.

TALLMAN, Susan. The Contemporary Print: From Pre-Pop to Postmodern. London: Thames \& Hudson, 1996. 


\section{LIST OF ILLUSTRATIONS}

Fig. 1. Front page of Signalz: Newsbulletin of the Centre for the Advanced Creative Study 1.1 (August 1964). (C) David Medalla and Paul Keeler.

Fig. 2. Carlos Cruz-Diez, "Photo-Strip Cruz-Diez," Signals 1.9 (August-September-October, 1965), 9.

Fig. 3. Detail of Signals 1.10 (August-September-October, 1965), 2-3 with text and image of Barnett Newman, Navrongo housewife, a review of Cruz-Diez, and Werner Heisenberg's "The Role of Modern Physics in the Present Development of Human Thinking." (C) David Medalla and Paul Keeler.

Fig. 4. Detail of Jesús Rafael Soto photo by Clay Perry in Signals 1.10 (November-December, 1965), 10-11. C David Medalla and Paul Keeler.

Fig. 5. Back cover of Signals 1.10 (November-December, 1965), 24 with Jesús Rafael Soto, The Little Yellow, 1965. (C) David Medalla and Paul Keeler; (C) Jesús Rafael Soto.

Fig. 6. Marcel Broodthaers, La Signature, Serie 1. Tirage illimité, 1969. Silkscreen on paper. (C) Marcel Broodthaers.

Fig. 7. Detail of front and back covers folded out of Signals 1.10 (November-December, 1965). . (C) David Medalla and Paul Keeler; (C) Jesús Rafael Soto.

Fig. 8. Front cover of Signals 2.11 (January, February, March, 1966) with Alejandro Otero 49 por ciento, 1965. (C) David Medalla and Paul Keeler; (C) Alejandro Otero.

Fig. 9. Medalla Cloud Canyon images in Signals 1.2 (September, 1964), 8. (c) David Medalla and Paul Keeler.

Fig. 10. Back cover of Signals 1.8 (June-July, 1965). C David Medalla and Paul Keeler.

Fig. 11. El Lissitzky, Lenin Tribune Proposal, 1920, gouache, india ink, and photomontage on cardboard, $63.8 \mathrm{x}$ $48 \mathrm{~cm}$.

Fig. 12. Detail of David Medalla, "Found-Poem for Otero," Signals 2.11 (January, February, March, 1966), 24. (C) David Medalla and Paul Keeler.

Fig. 13. David Medalla, "Found-Poem for Takis," Signals 1.7 (April-May, 1965), 12. @ David Medalla and Paul Keeler. 